\title{
Human Development and Tourism Specialization. Evidence from a Panel of Developed and Developing Countries
}

\author{
Bianca Biagi ${ }^{1}$, Maria Gabriela Ladu ${ }^{2}$ \\ University of Sassari, CRENoS \\ and \\ Vicente Royuela ${ }^{3}$ \\ AQR-IREA, University of Barcelona
}

\author{
1 Dipartimento di Scienze Economiche e Aziendali - CRENoS \\ University of Sassari \\ via Muroni, 25 \\ 07100 Sasari - Italy \\ bbiagi@uniss.it \\ phone number : +39079213511 \\ fax: +39079 213002 \\ 2 Dipartimento di Scienze Economiche e Aziendali - CRENoS \\ University of Sassari \\ via Muroni, 25 \\ 07100 Sasari - Italy \\ mgladu@uniss.it \\ phone number : +39 079213511 \\ fax: +39079213002 \\ 3 AQR-IREA, Departament d'Econometria, Estadìstica i Economia Espanyola \\ Universitat de Barcelona, Spain \\ vroyuela@ub.edu \\ phone number: +34 934021824 \\ fax: +34934021821
}

Summary: The analysis of the relationship between tourism and human development points to a positive link between these activities, basically by means of the improvement of economic conditions. In the present study we analyze whether and to what extent this relationship remains positive under different circumstances. We examine a selection of 63 countries from 1996 to 2008 and consider the Human Development Index plus a composite indicator of the tourism market as a whole. Findings confirm that, on average, tourism is positively associated with human development, particularly education (i.e., literacy rate), although the association may be affected by circumstances.

Key words: Human Development Index, tourism development, capability approach, externalities $J E L-015,010$, D62. 


\section{INTRODUCTION}

For many countries, the tourism sector represents a significant source of economic growth. The positive effect of tourism on local and national economies depends on the nature of the tourism product: a bundle of goods and services, the majority of which are location specific. As a result, the economic impact of tourism is linked to its unique characteristics: an ample and interrelated set of locally provided services directly and indirectly linked to the tourist experience (accommodation, restaurants, bars, cultural attractions, local transports, health services, waste management, and so on). From an empirical point of view, the impact of the tourism sector at a regional and national level has been widely explored by scholars. Many of these scholars investigate the Tourism-Led-Growth (TLG) hypothesis, which specifically refers to the economic impact of international tourism arrivals, receipts, or consumption in developed or developing countries. A fundamental literature review of TLG empirical analysis has been performed by Sinclair (1998); however, since the 1990s, the number of studies on this topic has increased remarkably (Bimonte et al., 2012). The majority of TLG studies focus on a single country; however, a few consider more extensive samples (for European countries, see Paci and Marrocu, 2014; for countries worldwide, see Lee and Chang, 2008, and Figini and Vici, 2010). Overall, applied research reaches the conclusion that the relationship between tourism and economic growth is positive and particularly robust when countries are small or specialize in tourism (Vanegas and Croes, 2003, Brau et al., 2007).

All the above-mentioned studies explore the relationship between tourism and development by means of an economic indicator: real GDP. The underlying assumption of the studies is that wealth is strongly correlated to human development, well-being, or quality of life. As is well known, many scholars discuss the use of GDP as the sole indicator of quality of life or economic progress (see Kenny 2005 for an updated literature review). Specifically, for Nobel Prize scholar Amartya Sen (1987, 1993, 1999), income and consumption are just components of well-being, while the most crucial factor is the capability of individuals to achieve conditions in life. For Sen, "capabilities are notions of freedom, in the positive sense: what real opportunities you have regarding the life you lead" (Sen, 1987, p.36). Since 1990, the United Nations Development Programme (UNDP) has used the Human Development Index (HDI) as an alternative indicator to measure human achievements. HDI is a composite statistic used to rank countries according to several development dimensions, such as life expectancy, education, and income. Since its introduction, mainstream economists have criticized the use of HDI rather than GDP (for a review see Klugman et al., 2011), and have mentioned two main shortcomings: the methodology and variables used to build the index and the redundancy of the index in respect to GDP. Due to these criticisms, a new version of HDI has been proposed. Redundancy of the index in respect to GDP refers to the high correlation between the level of GDP per capita and the HDI (McGillivray, 1991). However, this criticism has been challenged by studies that find evidence of non-linear link between GDP and other possible indicators of quality of life (Kenny, 2005, p.2). They find also that the correlation between the change in HDI and the growth of GDP per capita is not as strong as the correlation in these factors' levels, and that such a link is even weaker when one calculates the correlation between the change in the non-income component of HDI and GDP growth (Klugman et al., 2011). 
The main purpose of the present work is to study the relationship between tourism and human development à la Sen, using the revised version of HDI. Specifically, we show that the relationship between tourism and a broader concept of development needs to be investigated more in depth, and using GDP per capita is insufficient when the purpose is to investigate whether tourism affects human development. Unlike the connection between tourism and economic growth, the relationship between tourism and human development has not received much attention in the literature. An exception is presented by the study of Croes (2012), who analyzes the existence, nature, and direction of a possible relationship between tourism and human development in Nicaragua and Costa Rica from 1990 to 2009.

On this line of research, the present work investigates the link between tourism and human development for a panel of 63 countries, both developed and developing and both urbanized and rural, from 1996 to 2008. Our findings confirm that, on average, tourism is positively associated with human development, but in small and developed countries this relationship tends to be negative, suggesting that above a certain threshold tourism development produces some types of negative externalities. Furthermore, component-bycomponent analysis of the relationship with tourism and HDI indicates that investing in tourism sector is important not only to achieve economic growth but also to improve human development, specifically in one dimension of HDI - local education. This result suggests the need to further study the role of tourism for human development beyond the pure economic growth effects.

The paper is structured as follows. Section 2 presents the literature review. Section 3 analyzes the Human Development Index, while sub-section 3.1 investigates the redundancy of HDI versus GDP. Section 4 describes the tourism data. Section 5 presents a descriptive analysis and comparison of HDI and tourism development. Section 6 illustrates the empirical models. Section 7 shows the main results, the relationship between the tourism index and the HDI component by component, and inspects the role of the size of the countries and the degree of development. Robustness checks implemented to test the stability of the parameter under analysis are illustrated in Section 8. Finally, Section 9 discusses the results and offers some tentative conclusions.

\section{LITERATURE REVIEW}

As has been investigated in tourism literature, tourism activity may produce negative or positive effects on resident quality of life. The positive impacts regard primarily the economic sphere, such as the increase of job opportunities and local income. However, they might also regard the increase in the opportunities for resident population to enjoy local entertainment, such as cultural amenities and recreational services. On the other side, negative impacts occur when, for instance, the cost of living increases due to the extra demand for second homes or when the price of local products increases due to the presence of tourists (Biagi et al., 2012); other types of negative effects may arise in the case of intensification of local crime (Schubert, 2009; Biagi and Detotto, 2014) and possible problems related to crowd and environmental pressures on the urban and natural equilibrium (Andereck et al., 2007, Lindberg et al., 2001).

Apart from some exceptions, the vast majority of the tourism literature analyzing the hosttourism relationship focuses on quality of life of residents and, specifically, on their perceptions of the tourism impacts; these studies use surveys in which residents answer 
questions about the influence of tourism in their own life or in their community life. The main assumption of such studies is that the effect of tourism on resident well-being and, therefore, the success of a tourism destination will depend on the "positive" attitude of residents toward tourists (Purdue et al., 1990). This field of research applies the so-called social exchange theory to the tourism-host relationship and assumes that "social relations involve an exchange of resources among social actors; social actors seek mutual benefits from the exchange relationship" (Ap, 1990, p.669; Ward and Berno, 2011). The social exchange, therefore, implies interaction among actors. A negative resident's perception of the impact implies an asymmetric and unbalanced exchange (Ap, 1990). Andereck et al. (2007) find that for the Anglo and Hispanic populations in the southwestern United States, tourism has a positive impact on the economy of their communities, but they have a different opinion regarding the other types of impacts such as socio-cultural and environmental ones. In the case of Arizona, Andereck and Nyaupane (2010) find that the frequency with which residents interact with tourists and the local impact of tourism in terms of local employment affect the positive perceptions of the resident population. Aref (2011) shows that the strongest tourism impacts in Shiraz (Iran) are linked with emotional and community well-being, income, and employment, while health and safety well-being are found to be marginal. Yu et al. (2011) conclude that perceived social costs have no significant effect on residents in Orange County (Indiana, United States). The authors explain this result by the fact that tourism development in the case under analysis is in the initial development stage, so residents are anticipating positive effects and may have demonstrated a higher tolerance toward tourism-induced social costs. Figini et al. (2009), studying one of the major Italian seaside destinations, show that residents consider the presence of tourists as a positive means of improving their life conditions (not strictly in an economic sense).

Overall, the results highlight that economic impact is perceived mostly as positive, but other types of impacts are also considered important. One of the main shortcomings of these studies is that they are mainly qualitative and investigate the host-tourist relationship in specific places and in one point in time; hence they neglect possible medium long-run impacts of the tourism activity on the quality of life of residents. In a recent work, new empirical insights come from Marrocu and Paci (2011) that analyzing a cross section of 199 European regions (EU15) by using spatial econometric techniques provides empirical evidence that tourism can be a channel for transmitting new ideas and knowledge for local firms and regions.

Croes's work is a first attempt to open a line of research, but in our view, it presents some limitations. First, it does not clarify the underlying mechanism of the tourism-human development relationship. In other words, it does not clearly explain why (or how) the presence of tourists should affect HDI. Second, it finds inconclusive results. Third, it investigates only the case of two developing countries without considering any counterfactual evidence. Finally, it measures tourism by means of a demand-side indicator (tourism receipts) rather than market indicators (demand and supply) that would capture the overall effect of tourism-related activities in the countries studied.

Tourism is a bundle of goods and services that can only be consumed in the place of production. Hence, consumers (tourists) and producers (residents) interact with each other at the market place (tourism destinations). This paper applies the so-called social exchange theory to the tourism-host relationship and assumes that "social relations involve an exchange of resources among social actors; social actors seek mutual benefits 
from the exchange relationship" (Ap, 1990, p.669; Ward and Berno, 2011). The literature analyzing the tourism-resident relationship is vast (among others: Purdue et al., 1990; Andereck et al., 2007; Figini et al., 2009; Andereck and Nyaupane, 2010; Aref, 2011, Yu et al., 2011; Marrocu and Paci, 2011). Despite the fact that some scholars recognize that the possible effect of the host-resident relationship is the increase in "...education of indigenous citizens by exposing them to other people and cultures..." (Ankomah and Crompton, 1990), overall, applied research does not empirically investigate this possible impact.

\section{HUMAN DEVELOPMENT INDEX}

The Human Development Index (HDI) is a composite statistic used to rank countries according to several development dimensions: life expectancy, education, and income. It was created by two economists, Mahbubul Haq and Amartya Sen, in 1990 and is published by the United Nations Development Programme. The HDI has helped to shift attention away from the focus on economic growth as the objective of development policies. Nevertheless, criticism has forced improvement since the initial definition. Klugman et al. (2011) list three aspects of the HDI. First, there is the choice of the indicators; for example, the list of capabilities is much wider than the short list of considered variables. These indicators have been replaced and improved over the years. Second, there is the functional form, which has been replaced since 2010 from an arithmetic average to a geometric average of three separate indexes, each computing on a scale where a value equal to 1 means the country has the maximum value in every considered dimension. The new formula is characterized by some level of complementarity and substitutability between the basic variables.

The 2010 definition of the HDI considers the new functional form and a list of new indicators. The UNDP has defined the Hybrid HDI, a systematic assessment of trends in key components of human development over the past 40 years. ${ }^{1}$ The Hybrid HDI, which incorporates several changes, is computed as follows:

$$
\text { Hybrid HDI values, } H D I=\sqrt[3]{\text { Lifex } * E D U x * G D P x}
$$

where:

$$
\begin{gathered}
\text { Lifex }=\frac{\text { Life }-20}{83.166(\text { Japan }, 2010)-20} \\
G D P x=\frac{\ln (G D P)-\ln (163.28143(\text { Liberia }, 1995)}{\ln (106769.74(U A E, 1977))-\ln (163.28143(\text { Liberia }, 1995))} \\
E D U x=\sqrt[2]{\text { Litx } * \text { GERx }}
\end{gathered}
$$

and:

$$
\begin{gathered}
\text { Litx }=\frac{(\text { Lit }-0)}{99(\text { several countries, several years })-0} \\
\text { GERx }=\frac{\text { GER }-0}{115.8192(\text { Australia }, 2002)-0}
\end{gathered}
$$


where Lit is the literacy rate, GER the Combined Gross Enrolment Rate, Life the Life Expectancy at Birth, and GDP the Gross Domestic Product per capita, with PPP adjusted and measured in dollars.

The third criticism listed by Klugman et al. (2011) addresses redundancy, given the high correlation between the index and its components. As a measure of development, Sagar and Najam (1998) note that HDI has become a relevant alternative to the traditional onedimensional measure of development (GDP per capita), given that HDI captures more dimensions of development. Nevertheless, rich countries are usually healthier and more educated than poor countries. In fact, the correlation between all indicators for any year is usually above 0.90 . The redundancy of the evolution of these indicators over time is, however, unclear. Klugman et al. (2011) find no significant correlation between growth and improvements in human development in a sample of 135 countries from 1970 to 2010. Consequently, the redundancy argument may disappear if one looks at changes rather than at levels.

\subsection{On the redundancy of HDI versus GDP}

Here we further investigate the possible redundancy between HDI and GDP in our sample. With this purpose, we develop three exercises. Firstly, we have computed the correlation coefficients between the HDI, the Social HDI (an index equal to the geometric average between Education and Life Expectancy rate indexes: Social HDI $=\sqrt[2]{\text { Lifex } * \text { EDUx }}$, and all development indicators. Table 1 shows the correlation coefficients by using raw data, by controlling country and time effects, and by using yearly growth rates. As expected, all variables are highly correlated with regard to their levels. In contrast, once we look at changes over time (by controlling for country fixed effects or by looking at yearly changes), the correlations between the economic dimension and the social dimension of development diminish or even collapse in our sample.

Secondly, we look at the international disparities in living standards. Picture 1 displays the evolution of the standard deviation between countries over our period of analysis. We observe that an increasing inequality in economic terms is accompanied by a decreasing inequality in social development. Consequently, one should worry less about income when nearly everything that matters is converging (Kenny, 2005).

Finally, we computed two alternative regressions, where the growth of GDP and the Social HDI between 1996 and 2008 were regressed against the same set of independent variables from 1996: the initial value of the endogenous variable, openness, investment rate, inflation, and government consumption. We could not find any variable that was simultaneously significant in the two considered regressions (Table 2), which can be interpreted as two development dimensions with different sources and determinants.

\section{[TABLES 1 AND 2]}

[PICTURE 1]

Overall, if the Tourism-Led Growth hypothesis is confirmed in the literature, it is reasonable to wonder if one can also discuss the Tourism-Led Development hypothesis, as the economic and the social dimensions of development may not follow parallel processes. 


\section{TOURISM DATA}

How important is tourism in a country? Usually, tourism activity on the supply side is measured by using the number of tourism accommodations, rooms, beds and so on; while on the demand side is measured by considering tourism arrivals, nights of stay, tourism receipts etc. In order to check how tourism affects development, one can analyze the impact of every variable or concentrate the analysis on only one of them, such as tourism receipts. As a matter of fact, tourism literature use single indicators on the supply or demand side to capture tourism specialization. On the supply side, Defert (1967) measures the importance of tourism in a regional economy using the ratio of the number of tourist beds to the resident population. On a similar line, Lundgren (1966) uses the ratio of the resident population to the number of tourist accommodation establishments respect to the index of Defert, the more specialized regions will show lower value of the index- Moreover, the so-called touristic affluence spatial index by Lozato-Giotart (1985) is computed as the ratio of the number of tourist accommodation establishments to the surface area in $\mathrm{km} 2$. More recently, Vaccaro (2007) proposes the composite rate of accommodation function as the ratio of the number of beds in all accommodation establishments to the resident population times the surface area in $\mathrm{km} 2$. On the demand side, Neves and Maças (2008) measures specialization by using three separate indicators such as tourism arrivals as a population proportion, tourism receipts as a percentage of exports, and as a percentage of gross domestic product. Besides, Yang (2012) uses location quotient of tourism revenues that is a measurement of provincial tourism specialization relative to the whole country. The types of indicators/variables used by the academic studies is rather vast, this is surely a shortcoming that reflects the lack of a commonly accepted definition of tourism specialization at both international, national and regional level. As Perez et al. (2014, p.37) well explain "there is no consensus on the definition of Tourism specialization. Which variable should we use to determine if a region is specialized or not? Actually, even if tourism is, by definition, a demand - side phenomenon, it affects the supply - side and we are able to measure it from this point of view as well. The authors also recognize that a more comprehensive approach is to consider the both sides of the market. However, only few cases use composite measures in order to capture this complexity. In this line, the present work finds evidence that a composite index rather than single variables is more suitable to capture the effect of tourism on HDI (see Section 8).

As suggested by the authors, the composite index includes indicators of tourism supply and demand. It is worth noting that giving the lack of data at an international level we were forced to select the most completed variables available in the UNWTO database. As a matter of fact, building the tourism database has not been an easy task due to the difficulty of finding tourism variables for the largest number of countries (63) over the longest time span (13 years). Based on those two constraints three variables have been selected from the World Tourism Organization (UNWTO) database. One variable on the supply side (rooms in hotels and similar) and two variables related to the demand side (tourism expenditures and tourism arrivals). The variables, adjusted for the size of the country $\left(\mathrm{km}^{2}\right)$, are the following:

1. Total number of rooms in hotels and similar establishments (Rooms). This variable represents a proxy for the number of firms operating in formal tourist accommodation (supply side of the market); it also represents a proxy for local amenities like bars, restaurants, and cultural events but also for local public services. The variable is 
expected to have a positive effect on HDI, mainly through the rise of GDP but also for the overall improvement of the quality of life and, therefore, health, safety, and life expectancy of the resident population (Aref, 2011). According to recent studies (see for an instance Andereck, 2007), the presence of the tourism industry contributes to improving the quality and quantity of amenities "that help the communities to attain desirable living environments" (p. 484). Conversely, it is possible that the effect of the tourism industry on HDI would turn to be negative. This occurs when negative externalities prevail such as, for instance, environmental degradation and pollution (Shubert, 2009).

2. Tourism expenditures of inbound tourists (Exp_total). This variable refers to "the amount paid for the acquisition of consumption goods and services, as well as valuables, for own use or to give away, for and during tourism trips" (UNWTO, 2008, p.31).

3. Tourism arrivals in hotels and similar establishments (Arr_Overn). This variable refers to the number of persons who arrive at a tourist accommodation and check in. The increase of arrivals in destination countries may have direct and indirect positive effects on the HDI components. First, it might increase the GDP: tourism arrivals affect tourism expenditures and therefore national GDP (Sinclair, 1998; Lee and Chang, 2008; Figini and Vici, 2010; Bimonte et al., 2012; Paci and Marrocu, 2014). Second, tourism arrivals might have an indirect effect on GDP trough knowledge spillovers. The presence of tourist in destinations might represent an extra channel for transmitting new ideas and knowledge to local firms, increasing their productivity and, therefore, national GDP (Marrocu and Paci, 2011). Third, the presence of tourists in the destination countries might also affect other components of HDI. According to the social exchange theories, tourists and residents in destinations interact among them (Ap, 1990; 1992). This interaction might affect indigenous citizens by exposing them to other people and cultures and this effect can be particularly strong in the case of developing countries as found by Ankomah and Compton, 1990. Conversely, tourism arrivals may have a negative effect on HDI when the presence of visitors decreases the quality of life of the resident population due to excessive crowds, congestion, noise, and lack of safety (Andereck et al. 2007, Lindberg et al. 2001). The resident-host social relationship might produce a positive or negative attitude of residents toward tourists that depends on the resident perceptions of the net effect of tourism activity for the local community (Ap, 1992, Figini, 2007, Andereck et al., 2007, Aref, 2011).

We are aware that assuming Arrow's impossibility theorem (1963) which shows that no perfect aggregation convention can exist and several alternatives arise for building composite indexes, such as using principal components analysis, averaging the standardized variables, and other procedures. As our purpose is not finding the best composite index, we follow the applied literature and use the same method of Biagi et al. (2012, 2015a, 2015b), the Van der Waerden (VdW) ranking score. It is a multidimensional measure in which each variable has the same weights in the final index, as we understand that any weighting scheme can be under criticism. The VdW is a ranking score, a type of fractional rank, defined as: 


$$
V d W_{i, t}=\frac{R_{i, t}}{(n+1)}
$$

where

$$
\begin{aligned}
& V d W_{i t}=\text { Var der Waerden rank for country } i \text { at time } t \\
& R_{i, t}=\text { rank of each country } i \text { at time } t \\
& \text { for } \mathrm{i}=1, \ldots 76 \text { countries and } \mathrm{t}=1996, \ldots 2008 \text { years. }
\end{aligned}
$$

The VdW fractional rank is a simple method for standardizing scores so that they range from $1 /(n+1)$ to $n /(n+1)$. The advantage of the VdW metrics is that it combines the efficiency of the ANOVA analysis with the robustness of the Kruskal-Wallis metrics when the normality assumptions do not hold. Methods based on rankings are not affected by outliers and allow us to follow over time the performance of countries in terms of relative positions. However, individual performance in absolute terms cannot be evaluated as information on levels is lost. After having computed the VdW index for each variable, which was expressed in relative terms with respect to every country's total area, the average of the three scores is calculated to obtain the final index of tourism for each location under analysis:

$$
\text { Tourism Index }{ }_{i t}=\frac{\sum_{j=1}^{3} V d W_{i t}}{3}
$$

where $j$ is the total number of variables in the index. In this case, a higher score corresponds to more touristic areas. In our view, the main advantage of using this method to build the tourism index is its computational simplicity. Furthermore, the presence of few variables makes simpler and more easily interpretable the connections between the single variable inside the index and each variable inside the HDI. Other works have used composite indices based on rankings. OECD (2008) reports two examples using rankings: the Information and Communications Technology Index (Fagerberg, 2001) and the Medicare Study on Healthcare Performance (Jencks et al., 2003). Biagi et al. (2012) explore the effect of tourism on the house market in 377 Sardinian municipalities (Italy) ${ }^{3}$, Biagi et al. (2015a, 2015b) investigate the effect of tourism in the Italian house market using respectively panel data and mixture models. Map 1 shows the results of the index for the whole sample plus the top and bottom countries according to the 2008 index.

\section{[MAP1]}

\section{HDI AND TOURISM DEVELOPMENT: A DESCRIPTIVE ANALYSIS}

Having defined the key variables in our analysis, we need to consider whether, a priori, there is any relationship between them. Considering all countries for which we have information regarding both the HDI and our Tourism Index, the final sample includes 63 countries over the time span 1996 -2008(for the final list of the countries see Table A1.1 in Appendix 1). Table 3 presents the quantitative summary of our key variables. In addition, Figures 2 to 4 display the overall, within and between variation of the tourism and HDI indices. Looking at the descriptive statistics, we firstly acknowledge the fact that the standard deviation between countries in both the HDI and the Tourism Index is much 
wider than the within one. This result confirms the diversity of the considered sample and the need for further controlling such specificities.

By looking at the correlation between the HDI and the Tourism Index we acknowledge the fact that more developed countries are the ones with higher Tourism Index (correlation up to 0.67 ), what can be seen in figures 1 and 3. Nevertheless, the correlation almost vanishes once we control for country fixed effects $(0.08$, see figure 2$)$ or when we use growth rates, (0.093). Interestingly, once country and time effects are controlled for, the correlation rises again, although it remains low (0.238). The rest of the variables exhibit a similar behavior, with the log of GDP and the literacy rate being those with higher values once time and country effects are controlled for or growth rates are used. All in all, these results point to the need to control for country characteristics in order to isolate the relationship between tourism and human development.

[TABLE 3]

[FIGURES 2, 3 AND 4]

\section{EMPIRICAL MODEL}

The empirical model we use in this paper considers development, proxied by HDI or its components, as a function of the Tourism Index plus a list of control variables. We follow the literature on the determinants of cross-country differences in economic growth. This literature tends to rely on OLS regressions of accumulated growth rates over initial values of explanatory variables, and results are interpreted as measuring the long-run effects of those variables on subsequent economic growth. In particular, we follow the method of economic growth analysis developed by Sala-i-Martin et al. (2004). Out of 67 possible explanatory variables, they find 18 are significantly related to long-run growth over 1960 to 1996. The results suggest that among these 18 variables the main determinants for growth are the initial level of per capita GDP - the neoclassical idea of conditional convergence - and variables for natural resource endowments, physical and human capital accumulation, macroeconomic stability, and productive specialization (a negative and significant effect is found for the fraction of primary exports in total exports).

Rather than considering the growth rate of the HDI as a dependent variable, we follow Easterly's (2007) argument that the current level of a variable is the result of consecutive years of growth. Consequently, rather than looking at long-run effects, our empirical model will consider a contemporaneous correlation between the HDI and the Tourism Index as in the following equation:

$$
\begin{array}{r}
\text { HDI }_{i, t}=\alpha+\beta_{1} \text { Tourism }_{i, t}+\beta_{2} \text { Governement Consumption }_{i, t}+\beta_{3} \text { Investiment }_{i, t}+\beta_{4} \text { Openess }_{i, t} \\
+\beta_{5} \text { Inflation }_{i, t}+\beta_{6} \text { Urban population }_{i, t}+\beta_{7} \text { Urban } 1 M+\text { Population }_{i, t}+u_{i, t}
\end{array}
$$

where the control variables are defined as follows: ${ }^{4}$

1. Government Consumption (\% GDP). Grier and Tullock (1989) found a significantly negative relation between the growth of real GDP and the growth of the government share of GDP. 
2. Investment (\% GDP). This variable covers the total investments made by a particular country relative to its GDP. Harrod (1939), Domar (1946), and Rostow (1959) argue that countries with higher investment relative to their GDP are the fastest-growing countries, while countries in which investment has less weight are those with the lowest growth.

3. Openness. This variable reflects the sum of exports plus imports relative to GDP. In addition, this variable provides information about the extent to which an economy is open to the outside. Trade openness is a variable of interest because different agencies, including UNCTAD, argue that economic liberalization is a key factor in developing countries. From this point of view, it is often argued that trade restrictions have a negative effect on the efficiency of an economy because of the failure to exploit comparative advantage, and, therefore, they reduce aggregate output. If this were true, countries that reduced trade restrictions over time should experience higher economic growth.

4. Inflation. Stockman (1981) argues that in a "cash-in-advance" economy, higher anticipated inflation reduces economic activity, in which case greater growth in anticipated inflation would lower economic growth.

5. Urbanization: we consider Urban Population, that is, the percentage of the population that lives in urban agglomerations; and Urban1M, that is, the urban population in cities of more than 1 million (as a proportion of total population, Castells-Quintana and Royuela, 2014).

6. Population. Kormendi and Maguire (1985) argue that, under standard neoclassical growth theory, the steady-state growth rate should equal the growth rate of the labor force plus the growth rate of exogenous technological change. Thus, if all countries are in the steady state there should be a one-for-one effect of population growth on development. In the transition to the steady state, however, the effect may be less than one-for-one if either capital accumulation or labor force growth does not keep pace with population growth.

\section{RESULTS}

Before performing our empirical models, we test the time series properties of the key variables (HDI and Tourism) by applying panel unit root tests in order to avoid spurious correlation problems. Specifically, we test non-stationarity of our variables by using three types of panel unit root tests. Findings confirm stationarity and therefore that the investigated relationship does not suffer of problem of spurious correlation (see Table A1.4 in Appendix 1).

In the next tables we display the estimation results. The model employed assumes a panel specification, considering both cross-sectional and time-series information. The essential advantage of the model is that it is able to control for country and time specificities in the fixed-effects estimation. The estimations were performed using different procedures (see Table 4). All estimates gave a positive and significant result for the Tourism Index. The Hausman test applied to the fixed and random effects estimations rejected the null hypothesis of equal vectors of parameters, which implies potential endogeneity in the random effects estimation. Consequently, the fixed effects estimation is preferable to the random effects estimation, although in both cases tourism is significant. In fact, the pool 
estimates (columns 1 and 2) and the between (column 4) and random effects (column 5) consider the cross section information, which can be linked to the redundancy criticism, as countries' level of development may show information similar to countries' economic level. In contrast, the fixed effects estimate (column 3) captures the cross section information in the fixed effects, and, consequently, every parameter informs on the time series information of every country.

If we would assume a dynamic relationship between tourism and development, following Baltagi and Griffin (1984) and Pirotte (1999), the between estimates would represent the long-run impact of tourism on development, while the fixed effects estimates would capture the short-run impact of the variable, with the random effects parameter a mix of the between and fixed effects estimate. Consequently, one can consider a significant impact of tourism on development, both in the short and long run.

The basic results displayed in Table 4 show how tourism is significantly and positively correlated with development. This correlation is larger between countries than over time once long-term characteristics of countries are considered. Thus, the between parameter is three times larger than the fixed effects estimation. As both the HDI and the Tourism Index are composite measures, we do the numeric interpretation of the parameters in terms of standard deviations. Thus, the between estimation reports a standardized parameter of 0.22: country A with a Tourism Index 1 standard deviation higher than country B can be expected to have an HDI that is approximately 0.22 standard deviations higher. The fixed effects estimates report a standardized parameter equal to 0.079. Thus, if a country increases one standard deviation of its Tourism Index, we expect it to experience a parallel growth in its HDI of approximately 0.08 standard deviations.

[TABLE 4]

[TABLE 5]

After estimating the basic models, we analyze the relation between our Tourism Index and the HDI components. Columns 1 to 5 in table 5 displays the fixed effects estimates. The main results of the models are that the economic (log of GDP) and educational dimensions (Literacy Rate) are correlated with the Tourism Index. The result is particularly strong for the literacy rate. The analysis of social rather than economic dimensions to report development is not new in the literature. Kenny (2005) reports that one major factor behind global increases in literacy has been far more widespread access to basic education and that urbanization may indeed be a key factor because it is easier to provide social services to urban residents than to rural populations. As far as tourism supply is connected with urbanization, one can consider a connection with the provision of public services. Nevertheless, we admit that this argument should be valid for life expectancy, although it could not be the case for enrollment rates, as young people leave education to join the tourism sector. However, this effect can also be a consequence of social interactions among tourists and the resident population as postulated by social exchange theory (Ap, 1990; Andereck et al., 2007). In other words, it is likely that the presence of the temporary population with high education, high income, and an openminded attitude - such as international tourists - triggers changes in residents' aspirations and perspective on life. Furthermore, a recent work of Di Liberto (2013) shows a positive 
relationship between education variables (proxies for human capital) and tourism sector and economic growth concluding that both in developing and developed countries the impact of tourism is higher the higher the human capital endowments.

As considering country fixed effects and the included list of controls may be not enough for solving the potential if omitted variable bias, we check for the impact of the stage of development of each country as well as the specific characteristic of several small countries. Columns 6 and 7 in table 5 report the interaction of the Tourism Index with two dummies: size (below one million inhabitants) and development (developed countries according to the UN description of economic regions). The results confirm the significance of tourism in both cases, and do not report marginal significant results neither for small nor for developed countries. We also tested for non-linearities (not reported), which arise in pool and between estimates, but not in the fixed effects and random effects models. When significant, non-linearities stress a declining positive marginal effect of tourism on human development.

\section{ROBUSTNESS ANALYSIS}

This section shows the results of robustness check performed. Firstly, we regressed HDI on a list of alternative tourism indicators, considering single indicators and composite measurements (see Appendix 2 for details). The results in Table 6show how the indicators considering a single variable do not report robust significant parameters. Tourism arrivals are never significant, an aspect that deserves further research beyond our work, while tourism expenditure and rooms are significant if the transformation is logarithmic (tourism expenditure) or using the VdW metrics (Rooms). On the contrary, composite indicators are always significant. The chosen index in this work is the more significant tourism indicator, but not the one reporting higher adjustment (which is the model using the logarithmic transformation of Rooms). Overall, we believe that our strategy is valid as far as composite indices are capable of collecting the joint information of all tourism dimensions, and is robust, as far as all composite indices are able to report a significant impact of tourism on human development.

\section{[TABLE 6]}

Secondly, we examine the dynamic specification and the potential endogeneity of tourism. Croes (2012) analyses the relationship between tourism and human development in Nicaragua and Costa Rica by means of a cointegration analysis, with conflicting results. We extend the work of Croes going further the cointegration analysis made in his paper. Specifically, we run several dynamic specifications of the model to test if a temporal misspecification of the model would be forcing the results towards a false significance of tourism on human development. We first check for the inclusion of the tourism index with alternative lags. Table 7displays the results for different lags of the tourism index on human development. The relationship of the fixed effects specification is still significant after two lags.

As human development is expected to be persistent, we also run several alternative models to account for endogenous persistence. First, we run a Generalized Least Squares estimation (GLS) where we assume a first order autoregressive process on the error term. And second we run a dynamic estimation using the Blundell and Bond (1998) system 
Generalized Method of Moment estimation (GMM). Table 8displays these results in the first two columns. In both cases tourism is significant, which reinforces previous results. Finally, we also deal with potential endogeneity of tourism in the dynamic model. As is usual in System GMM estimations, we use internal instruments based on past values of the variable. The results, shown in column 3 of Table 10, still report a significant parameter for the tourism index, which reinforces all previous results. Finally, the fourth column of Table 8presents the GMM estimation where the Tourism index is regressed using second and third lags as instruments. Again the tourism parameter arises as significant, and the result (0.081) is close to the basic estimation in Table $4(0.0829)$.

\section{[TABLE 7]}

\section{[TABLE 8]}

\section{CONCLUSIONS}

The purpose of the present work is to study the relationship between human development and tourism development for a panel of 63 developed to developing and small to large countries. Applied research has already found a positive and significant relationship between tourism and economic growth (TLG hypothesis); conversely, in a few examples (Croes, 2012) very little attention is devoted to the relationship between tourism and a broader definition of economic progress, such as the Human Development Index (HDI) of UNDP, a measure of individual capabilities. Although one could think about redundancy between GDP and HDI, we find that when change in the non-income component of HDI (the Social HDI) and change in GDP are considered, rather than their levels, the correlation between the economic and social dimensions of HDI reduces or even collapses. Consequently, although the relationship between economic growth and tourism is important, it tells just one part of the story of the effect of tourism on development in terms of individual capabilities. Following Croes (2012), the dependent variable in our analysis is the HDI. In this work we have considered both specific tourism variables and a composite index of tourism, which captures the importance of the tourism market as a whole in the countries under analysis by looking at both the demand and supply sides.

Our findings suggest that investing in the tourism sector may have a strong and significant positive effect for human development in the destination countries. Furthermore, more in-depth analysis has revealed that the greatest effect regards local education (more specifically, the literacy rate). One possible explanation is the social exchange among tourists (demand) and residents (supply). The presence of a temporary population, such as foreign visitors, with a high level of education, high income, and an open-minded attitude may trigger changes in residents' aspirations and perspective on life. These positive effects suggest that policy strategies for promoting tourism attraction should consider the creation of infrastructures to be accessible to tourists, such as transport, restaurants, travel agencies, tour operators, tourism information offices, etc. Furthermore, territorial policy must be oriented to the improvement in education and skills in order to increase the standard of the local tourism management (Pedrana, 2013). Finally, public institutions should not only promote local culture and traditions as elements of tourist 
attraction, but also increase the local opportunities of interaction between tourists and residents.

Our results are robust to the specification of the composite tourism index and to estimation techniques, although several specific tourism variables do not report significant results. These findings suggest the need for further studies on the role of tourism in human development beyond the pure economic growth effects. Moreover, they also indicate the need to more deeply investigate the role of tourism on residents' quality of life using methodologies other than the analysis of resident perceptions through questionnaires.

\section{NOTES}

1. This dataset considers 135 countries over the 1970-2010 period. The Hybrid HDI is available at: http://hdr.undp.org/en/media/2010_Hybrid-HDI-data.xls

2. These variables have been accessed at http://statistics.unwto.org/

3. The exercise of Biagi et al. (2012) is based on a previous work of Biagi and Faggian (2004), in this context the tourism index is presented for the first time.

4. The sources, definitions, and descriptive statistics of such variables are displayed in tables A1.2 and A1.3 in Appendix 1. 


\section{REFERENCES}

Andereck K L, Vogt C A. 2000. The Relationship between Resident's Attitudes towards Tourism and Tourism Development Option. Journal of Travel Research39: 27-36

Andereck K L, Valentine K M, Vogt CA, Knopf R C. 2007. A Cross-cultural Analysis of Tourism and Quality of Life Perceptions. Journal of Sustainable Tourism15: 483-502.

Andereck K L, Nyaupane, G P. 2011. Exploring the Nature of Tourism and Quality of Life Perceptions among Residents. Journal of Travel Research50: 248-260.

Ankomah P K,Crompton J L. 1990. Unrealized Tourism Potential: The case of SubSaharan Africa. Tourism Management11: 32-39.

Ap J. 1990. Residents' perceptions research on the social impacts of tourism. Annals of Tourism Research17: 610-616.

Ap J. 1992. Residents' perceptions on tourism impacts. Annals of Tourism Research19: 665-690.

Aref F. 2011. The Effects of Tourism on Quality of Life: A Case Study of Shiraz, Iran. Life Science Journal8: 26-30.

Arrow K J. 1963. Social choice and individual values, 2nd edition, Wiley, New York.

Baltagi B H, Griffin JM. 1984. Short and Long Run Effects in Pooled Models. International Economic Review25(3): 631-645.

Biagi B, Faggian A. 2004, The Effect of Tourism on the House Market: the case of Sardinia, working paper, ERSA Conference - Porto.

Biagi B, Lambiri D, Faggian A. 2012. The Effect of Tourism on the Housing Market. Handbook of Tourism and Quality-of-Life Research, 635-652.

Biagi B, Detotto C. 2014. Crime as Tourism Externality. Regional Studies48(4): 693-709.

Biagi B,Brandano M G, Caudill S B. 2015, Tourism and house prices in Italy: a latent class approach, Tourism Economics, forthcoming DOI: 10.5367/te.2015.0470.

Biagi B, Brandano M G, Lambiri D. 2015, Does Tourism affect house price? Evidence from Italy, Growth and Change46(3): 501-528.

BimonteS, Brida J G, Pulina M, Punzo LF. 2012. Tourism and Growth. Stories of two Continents. Routledge Studies in the Modern World Economy, London.

Binder M, Georgiadis G 2011. Determinants of Human Development: Capturing the Role of Institutions. CESifo Working Paper, 3397.

Blundell R, Bond S. 1998. Initial conditions and moment restrictions in dynamic panel data models. Journal of Econometrics87: 115-143.

Castells-Quintana D, Royuela V. 2014. Agglomeration, Inequality and Economic Growth. Annals of Regional Science52(2): 343-366.

Croes R. 2012. Assessing Tourism Development from Sen's Capability Approach. Journal of Travel Research51: 542-554. 
Defert, P. 1967.Le taux de fonctiontouristique: mise au point et critique. Les cahiers du tourisme. Centre des Hautes Etudes Touristiques, Aix-en-Provence, C-13.

Di Liberto A. 2013. High skills, high growth: Is tourism an exception? The Journal of International Trade \& Economic Development: An International and Comparative Review 22: 749-785.

Domar E D.1946. Capital Expansion, Rate of Growth, and Employment. Econometrica14: 137-147.

Easterly W. 2007. Inequality does cause underdevelopment: Insights from a new instrument. Journal of Development Economics84: 755-776.

Fagerberg J. 2001.in Lundvall B. and Archibugi D. (eds.) Europe at the crossroads: The challenge from innovation-based growth in the Globalising Learning Economy, Oxford Press.

Figini P, Castellani M, Vici L. 2009. Estimating Tourism Effects on Residents: a Choice Modeling Approach to the Case of Rimini. Advances in Tourism Economics. New Developments, Berlin, Springer-Verlag, 145-164.

Figini P, Vici L. 2010. Tourism and Growth in a Cross-Section of Countries. Tourism Economics 16: 789-805.

Grier K,Tullock G. 1989. An empirical analysis of cross-national economic growth, 1951-80. Journal of Monetary Economics24: 259-276.

Harrod RF. 1939. An Essay in Dynamic Theory. The Economic Journal49: 14-33.

Human Development Report-HDR. 1990. United Nations Development Program (UNDP) New York, NY 10017, USA.

Jencks S F, Huff E D, Cuerdon T. 2003. Change in the quality of care delivered to Medicare beneficiaries, 1998-1999 to 2000-2001. Journal of the American Medical Association 289(3): 305-12.

Jolliffe I T. 2002. Principal Component Analysis, Series: Springer Series in Statistics, 2nd ed., Springer, NY.

Kenny C.2005. Why Are We Worried About Income? Nearly Everything that Matters is Converging. World Development33: 1-19.

Klugman J, Rodriguez F, Hyung JC. 2011. The HDI 2010: new controversies, old critiques. Journal of Economic Inequality 9(2): 49-288.

Kormendi R, Meguire P. 1985. Macroeconomic determinants of growth. Journal of Monetary Economics16: 141-163.

Krueger AB, Kahneman D, Schkade D, Shwaiz N, Stone AA. 2009. National Time Accounting: The Currency of Life, in Measuring the Subjective Well-Being of Nations: National Accounts of Time Use and Well-Being, University of Chicago Press.

Lee C C, Chang C P. 2008. Tourism development and economic growth: a closer look at panels. Tourism Management29: 180-192.

Lindberg K, AnderssonTD, Dellaert B GC. 2001. Tourism Development. Assessing Social Gains and Losses. Annals of Tourism Research28: 1010-1030. 
Lozato-Giotart, J.P. 1985.Géographie du tourisme. De l'éspacerégardé à l'éspaceconsommé, Collection Géograhie.Masson, Paris.

Lundgren, J.O. 1966. Tourism en Quebec. La Revue de geographie de Montreal, 20(2):59-73.

Marrocu E, Paci R. 2011. They arrive with new information. Tourism flows and production efficiency in the European regions. Tourism Management32: 750-758.

McGillivray M. 1991. The human development index: yet another redundant composite development indicator? World Development 19: 1461-1468.

Neves, T., Maças, N. 2008. Does tourism influence economic growth? A dynamic panel data approach. Applied Economics, 40: 2341 - 2441.

Paci R, Marrocu E. 2014. Tourism and regional growth in Europe. Papers in Regional Science, 93: S25-S50.

Pedrana M., 2013. Local economic development policies and tourism. An approach to sustainability and culture, Regional Science Inquiry Journal, V(1): 91-99.

Pérez-Dacal D., Pena-Boquete Y., Fernández M. 2014. Measuring Tourism Specialization: a Composite Indicator for the Spanish Regions, Almatourism, 9, 35-73

Pirotte A. 1999. Convergence of the static estimation toward the long run effects of dynamic panel data models. Economic Letters63: 151-158.

Purdue RR, Long PT, Allen L. 1990. Resident support for tourism development. Annals of Tourism Research17(4): 586-99.

Rostow WW. 1959. The stages of economic growth. The Economic History Review12: 116.

Sagar A D, Najam A. 1998. The human development index: a critical review. Ecological Economics25: 249-264.

Sala-i-Martin X, Doppelhofer G, Miller R. 2004. Determinants of Long-Term Growth: A Bayesian Averaging of Classical Estimates (BACE) Approach. American Economic Review94: 813-835.

Schubert S F. 2009. Coping with Externalities in Tourism - A Dynamic Optimal Taxation Approach. Competence Centre in Tourism Management and Tourism Economics (TOMTE), Free University of Bozen-Bolzano, Bolzano.

Sen A. 1987. The standard of living, Cambridge, University Press.

Sen A. 1993. Capability and well-being, in Nussbaum and Sen (Eds), The quality of life. Wider studies in development economies, Clarendon Press, Oxford.

Sen A. 1999. Development as Freedom, Oxford, Oxford University Press.

Sinclair M T. 1998. Tourism and Economic Development: A Survey. Journal of Development Studies34: 1-51.

Stockman A C. 1981. Anticipated inflation and the capital stock in a cash-in-advance economy. Journal of Monetary Economics8: 387-393.

UNWTO 2008. International Recommendations for Tourism Statistics, Department of Economic and Social Affairs- Statistic Division, Series M No. 83/Rev.1. 
Vaccaro, G. 2007.La statisticaapplicata al turismo, HoepliEditore, Milano.

Vanegas M, Croes R. 2003. Growth, Development and Tourism in a Small Economy: Evidence from Aruba. International Journal of Tourism Research5: 315-30.

Ward C. Berno T. 2011. Beyond social exchange theory: Attitudes towards tourists. Annals of Tourism Research38: 1556-1569.

Yang, Y. 2012. Agglomeration density and tourism development in China: An empirical research based on dynamic panel data model. Tourism Management, 33: 1347 - 1359.

You CP, Chancellor H, Cole S T. 2011. Examining the Effects of Tourism Impacts on Resident Quality of Life: Evidence from Rural Midwestern Communities in USA. International Journal of Tourism Sciences11: 161-186. 
TABLES AND FIGURES

Table 1. Correlation matrixes. HDI components.

\begin{tabular}{|lcccccc|}
\hline & $\begin{array}{c}\text { Hybrid } \\
\text { HDI }\end{array}$ & $\begin{array}{c}\text { Social } \\
\text { HDI }\end{array}$ & $\begin{array}{c}\text { GDP } \\
\text { lgdp }\end{array}$ & Life & Lit \\
\hline GDP & 0.773 & 0.660 & 1 & & & \\
lgdp & 0.955 & 0.857 & 0.865 & 1 & & \\
Life & 0.909 & 0.930 & 0.654 & 0.806 & 1 & \\
Lit & 0.887 & 0.918 & 0.535 & 0.778 & 0.753 & 1 \\
GER & 0.901 & 0.920 & 0.641 & 0.805 & 0.761 & 0.835 \\
\hline \multicolumn{7}{c}{ Country and time fixed effects } \\
\hline GDP & -0.008 & -0.228 & 1 & & & \\
lgdp & 0.416 & -0.084 & 0.434 & 1 & & \\
Life & 0.639 & 0.751 & -0.040 & -0.107 & 1 & \\
Lit & 0.313 & 0.462 & -0.504 & -0.188 & 0.105 & 1 \\
GER & 0.669 & 0.690 & -0.068 & 0.092 & 0.211 & 0.070 \\
\hline \multicolumn{7}{c}{ Growth rates } \\
\hline GDP & 0.187 & -0.126 & 1 & & \\
lgdp & 0.500 & -0.053 & 0.583 & 1 & & \\
Life & 0.480 & 0.591 & -0.040 & -0.077 & 1 & \\
Lit & 0.225 & 0.334 & -0.311 & -0.091 & 0.046 & 1 \\
GER & 0.687 & 0.791 & -0.034 & 0.014 & 0.096 & 0.013 \\
\hline
\end{tabular}


Table 2. GDP growth and Social HDI growth.

\begin{tabular}{lcccc} 
& \multicolumn{2}{c}{ GDP growth } & \multicolumn{2}{c}{ Social HDI growth } \\
\hline GDP & Coef. & (s.e.) & Coef. & (s.e.) \\
Social HDI & $-1.45 \mathrm{e}-06$ & $(2.43 \mathrm{e}-06)$ & & \\
Government cons. & $0.0286 *$ & $(0.0159)$ & 0.000664 & $(0.00221)$ \\
Investment ratio & 0.00489 & $(0.00762)$ & -0.00133 & $(0.00180)$ \\
Openness & 0.000273 & $(0.00106)$ & $-0.000308 * *$ & $(0.000151)$ \\
Inflation & 0.00247 & $(0.00206)$ & -0.000592 & $(0.000451)$ \\
Constant & 0.0447 & $(0.230)$ & $0.594 * * *$ & $(0.126)$ \\
Observations & \multicolumn{2}{c}{63} & \multicolumn{2}{c}{63} \\
$\mathrm{R}^{2}$ & \multicolumn{2}{c}{0.149} & \multicolumn{2}{c}{0.572} \\
\hline
\end{tabular}

Robust standard errors in parentheses. $* * * \mathrm{p}<0.01, * * \mathrm{p}<0.05, * \mathrm{p}<0.1$ 
Picture 1. GDP, HDI, and Social HDI, standard deviation 1996-2008.

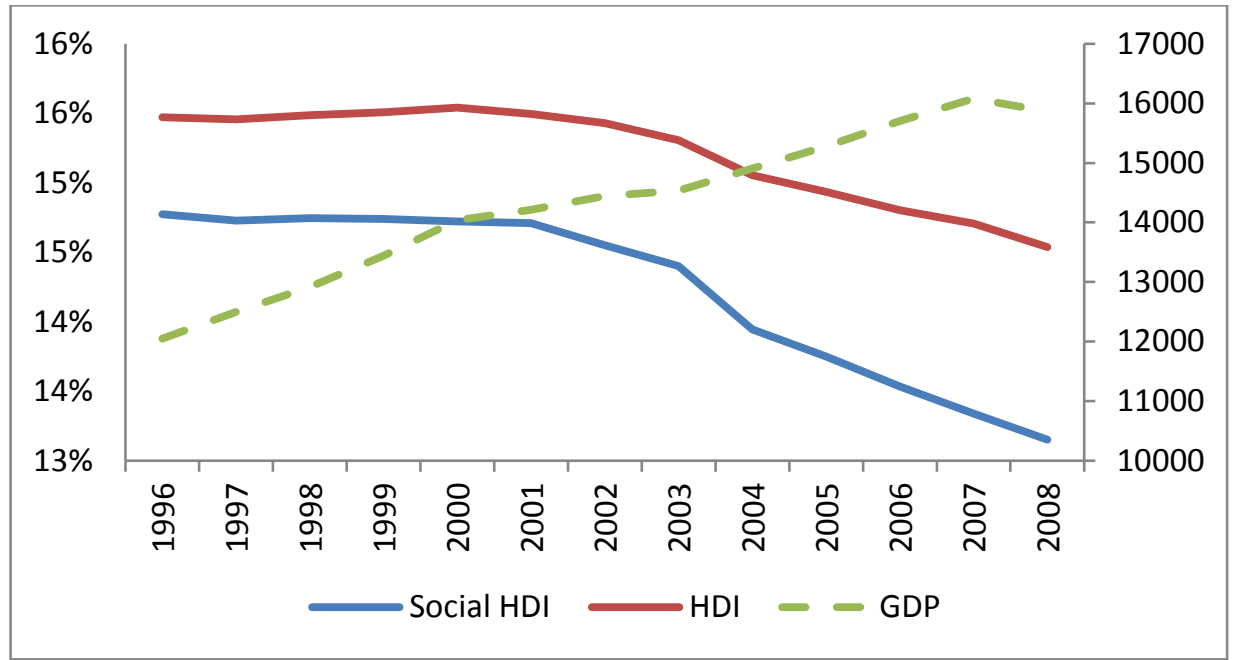




\begin{tabular}{|c|c|c|}
\hline Map 1. Tourism Index 2008 & Top & Bottom \\
\hline v & $\begin{array}{l}1 \text { ( }(0.983) \text { Singapore } \\
2(0.974) \\
\text { Dominican R } \\
3(0.948) \text { Maldives } \\
4(0.944) \text { Barbados } \\
5(0.913) \text { Mauritius } \\
6(0.896) \\
\text { Luxembourg } \\
7(0.87) \text { St. Lucia } \\
8(0.866) \text { Seychelles } \\
9(0.861) \text { Cyprus } \\
10(0.857) \text { Belgium } \\
11(0.848) \text { Austria } \\
12(0.823) \text { Grenada } \\
13(0.814) \text { Italy } \\
14(0.805) \text { Israel } \\
15(0.797) \text { Germany }\end{array}$ & \begin{tabular}{|l}
$62(0.199)$ Chile \\
$63(0.19)$ India \\
$64(0.19)$ Venezuela \\
$65(0.182)$ Togo \\
$66(0.165)$ Pakistan \\
$67(0.147)$ Australia \\
$68(0.117)$ Botswana \\
$69(0.117)$ Yemen \\
$70(0.113)$ Russia \\
$71(0.104)$ Paraguay \\
$72(0.069)$ Bolivia \\
$73(0.069)$ \\
Madagascar \\
$74(0.052)$ \\
SierraLeone \\
$75(0.026)$ Mali \\
$76(0.013)$ Niger \\
\end{tabular} \\
\hline
\end{tabular}


Table 2. Descriptive statistics

Std. Dev.

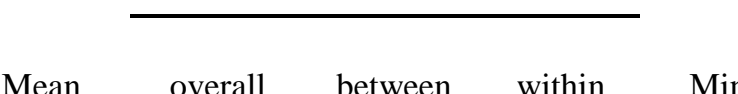

\begin{tabular}{lccccccccc}
\hline Tourism & 0.472 & 0.259 & 0.260 & 0.019 & 0.013 & 0.978 & 1 & 1 & 1 \\
index & 0.719 & 0.152 & 0.152 & 0.02 & 0.205 & 0.935 & 0.665 & 0.238 & 0.093 \\
HDI & 15340.7 & 14338.7 & 14268.4 & 2235.5 & 618.2 & 81101.3 & 0.559 & 0.028 & 0.173 \\
GDP & 9.116 & 1.141 & 1.142 & 0.131 & 6.427 & 11.303 & 0.669 & 0.263 & 0.186 \\
log GDP & 71.265 & 8.287 & 8.249 & 1.278 & 44.011 & 82.81 & 0.641 & 0.025 & -0.026 \\
Life Exp & 86.159 & 18.645 & 18.627 & 2.399 & 7.949 & 99 & 0.556 & 0.219 & 0.037 \\
Lit Rate & 75.514 & 17.251 & 16.86 & 4.183 & 16.542 & 115.8 & 0.483 & 0.067 & -0.001 \\
GER & & & & & & & & \\
\hline
\end{tabular}

Correlation with the Tourism Index

\begin{tabular}{|c|c|c|}
\hline $\begin{array}{l}\text { Raw } \\
\text { data }\end{array}$ & $\begin{array}{l}\text { Country and } \\
\text { time fixed } \\
\text { effects }\end{array}$ & $\begin{array}{c}\text { Growth } \\
\text { rates }\end{array}$ \\
\hline
\end{tabular}

.


Correlation between the Tourism Index and the HDI. Overall Variation.

Picture 2.

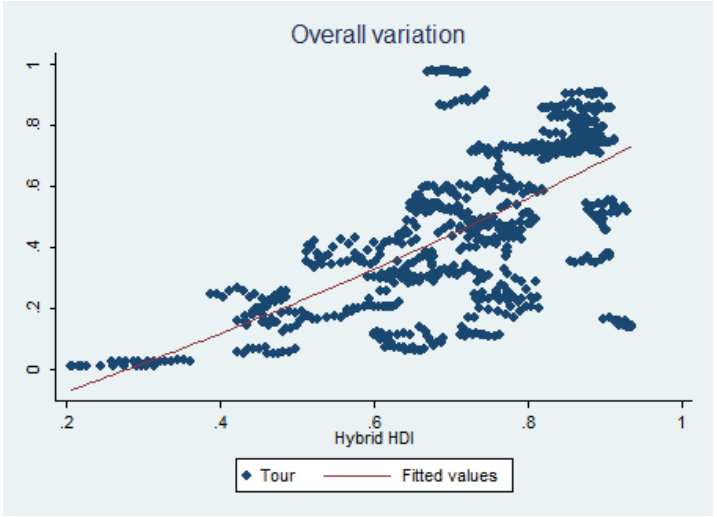

Picture 3. Within Variation

Picture 4. BetweenVariation
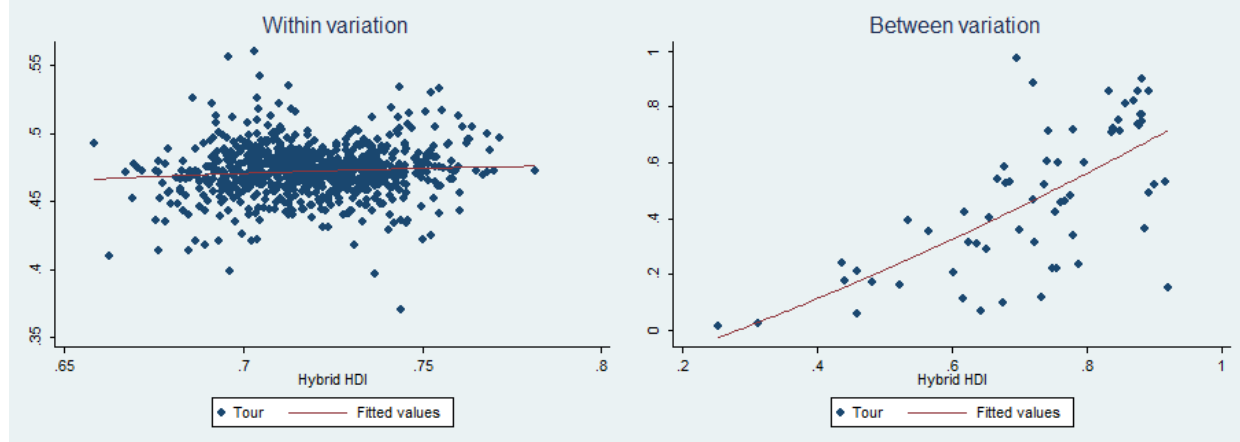
Table 4. Basic model. Hybrid Human Development Index.

\begin{tabular}{|c|c|c|c|c|c|}
\hline & (1) & (2) & (3) & (4) & (5) \\
\hline & Pool -1 & Pool -2 & $\begin{array}{l}\text { Fixed } \\
\text { Effects }\end{array}$ & Between & $\begin{array}{c}\text { Random } \\
\text { Effects }\end{array}$ \\
\hline Tourism & $0.260 * * *$ & $0.264 * * *$ & $0.0829 * * *$ & $0.264 * * *$ & $0.130 * * *$ \\
\hline Gov. Consumption & $\begin{array}{c}(0.0139) \\
-0.00380 * * *\end{array}$ & $\begin{array}{c}(0.0143) \\
-0.00351 * * *\end{array}$ & $\begin{array}{c}(0.0264) \\
-3.27 \mathrm{e}-05\end{array}$ & $\begin{array}{l}(0.0423) \\
-0.00367\end{array}$ & $\begin{array}{c}(0.0287) \\
-0.000650\end{array}$ \\
\hline Investment & $\begin{array}{l}(0.000695) \\
0.00105 * * *\end{array}$ & $\begin{array}{c}(0.000683) \\
0.000961 * * *\end{array}$ & $\begin{array}{c}(0.00106) \\
0.000903 * * *\end{array}$ & $\begin{array}{l}(0.00295) \\
0.000926\end{array}$ & $\begin{array}{c}(0.00116) \\
0.000948 * * *\end{array}$ \\
\hline Openness & $\begin{array}{c}(0.000336) \\
-0.000133^{* *}\end{array}$ & $\begin{array}{c}(0.000337) \\
-0.000178 * * *\end{array}$ & $\begin{array}{l}(0.000332) \\
-0.000121\end{array}$ & $\begin{array}{l}(0.00162) \\
-0.000195\end{array}$ & $\begin{array}{l}(0.000301) \\
-6.84 \mathrm{e}-05\end{array}$ \\
\hline Inflation & $\begin{array}{c}(5.74 \mathrm{e}-05) \\
-0.000305^{*}\end{array}$ & $\begin{array}{l}(5.87 e-05) \\
-0.000243\end{array}$ & $\begin{array}{l}(0.000121) \\
-6.77 \mathrm{e}-05^{*}\end{array}$ & $\begin{array}{l}(0.000268) \\
-0.000394\end{array}$ & $\begin{array}{c}(0.000121) \\
-8.42 \mathrm{e}-05^{* *}\end{array}$ \\
\hline Urban Population & $\begin{array}{l}(0.000169) \\
0.00460 * * *\end{array}$ & $\begin{array}{l}(0.000179) \\
0.00458 * * *\end{array}$ & $\begin{array}{l}(3.75 \mathrm{e}-05) \\
8.11 \mathrm{e}-05\end{array}$ & $\begin{array}{c}(0.00117) \\
0.00460 * * *\end{array}$ & $\begin{array}{l}(3.77 \mathrm{e}-05) \\
0.00165^{* *}\end{array}$ \\
\hline Urban1M & $\begin{array}{l}(0.000200) \\
-0.000285\end{array}$ & $\begin{array}{l}(0.000200) \\
-0.000313\end{array}$ & $\begin{array}{l}(0.000768) \\
-0.000274\end{array}$ & $\begin{array}{l}(0.000588) \\
-0.000342\end{array}$ & $\begin{array}{l}(0.000642) \\
-0.000173\end{array}$ \\
\hline Population & $\begin{array}{c}(0.000195) \\
6.51 \mathrm{e}-11 * * *\end{array}$ & $\begin{array}{c}(0.000197) \\
6.18 \mathrm{e}-11^{* * *}\end{array}$ & $\begin{array}{c}(0.000427) \\
2.21 \mathrm{e}-10 * * *\end{array}$ & $\begin{array}{c}(0.000734) \\
6.21 \mathrm{e}-11\end{array}$ & $\begin{array}{c}(0.000404) \\
8.41 \mathrm{e}-11 * * *\end{array}$ \\
\hline Constant & $\begin{array}{c}(0) \\
0.336^{* * *}\end{array}$ & $\begin{array}{c}(0) \\
0.322 * * *\end{array}$ & $\begin{array}{l}(8.24 \mathrm{e}-11) \\
0.627 * * *\end{array}$ & $\begin{array}{l}(5.02 \mathrm{e}-11) \\
0.343 * * *\end{array}$ & $\begin{array}{c}(0) \\
0.520 * * *\end{array}$ \\
\hline $\begin{array}{l}\text { Time Fixed Effects } \\
\text { Country Fixed Effects } \\
\text { Observations } \\
\mathrm{R}^{2}\end{array}$ & $\begin{array}{c}(0.0148) \\
\text { NO } \\
\text { NO } \\
819 \\
0.795\end{array}$ & $\begin{array}{c}(0.0165) \\
\text { YES } \\
\text { NO } \\
819 \\
0.800\end{array}$ & $\begin{array}{c}(0.0488) \\
\text { YES } \\
\text { YES } \\
819 \\
0.813\end{array}$ & $\begin{array}{c}(0.0605) \\
\text { NO } \\
\text { NO } \\
819 \\
0.802\end{array}$ & $\begin{array}{c}(0.0422) \\
\text { YES } \\
\text { NO } \\
819 \\
0.714\end{array}$ \\
\hline
\end{tabular}

Note: Robust standard errors in parentheses. ${ }^{*} * * \mathrm{p}<0.01,{ }^{*} * \mathrm{p}<0.05,{ }^{*} \mathrm{p}<0.1$.

Hausman test between RE and FE: 114.46 (p-val = 0.0002) 
Table 5. Fixed Effects estimates by HDI components and country characteristics

\begin{tabular}{|c|c|c|c|c|c|c|c|}
\hline & $\begin{array}{c}(1) \\
\text { GDP }\end{array}$ & $\begin{array}{c}(2) \\
\log \text { GDP }\end{array}$ & $\begin{array}{c}\text { (3) } \\
\text { Life Exp }\end{array}$ & $\begin{array}{c}\text { (4) } \\
\text { Lit Rate }\end{array}$ & $\begin{array}{c}\text { (5) } \\
\text { GER }\end{array}$ & $\begin{array}{c}(6) \\
\text { HDI by } \\
\text { Country Size }\end{array}$ & $\begin{array}{c}\text { (7) } \\
\text { HDI by } \\
\text { Development }\end{array}$ \\
\hline Tourism & $\begin{array}{c}311.3 \\
-5,573\end{array}$ & $\begin{array}{c}0.638 * * \\
(0.295)\end{array}$ & $\begin{array}{l}-0.372 \\
-2.906\end{array}$ & $\begin{array}{c}19.25 * * * \\
-6.476\end{array}$ & $\begin{array}{c}9.938 \\
(12.51)\end{array}$ & $\begin{array}{c}0.0805 * * * \\
(0.0260)\end{array}$ & $\begin{array}{l}0.0561 * \\
(0.0304)\end{array}$ \\
\hline Tourism * Small & & & & & & $\begin{array}{c}0.163 \\
(0.347)\end{array}$ & \\
\hline Tourism*Development & & & & & & & $\begin{array}{c}0.0957 \\
(0.0697)\end{array}$ \\
\hline Gov. Consumption & $\begin{array}{l}-307.4 * \\
(167.7)\end{array}$ & $\begin{array}{c}-0.0380 * * * \\
(0.00904)\end{array}$ & $\begin{array}{c}0.278 * * \\
(0.113)\end{array}$ & $\begin{array}{c}0.287 \\
(0.264)\end{array}$ & $\begin{array}{c}0.309 \\
(0.327)\end{array}$ & $\begin{array}{l}-4.48 \mathrm{e}-05 \\
(0.00106)\end{array}$ & $\begin{array}{l}1.11 \mathrm{e}-05 \\
(0.00106)\end{array}$ \\
\hline Investment & $\begin{array}{c}64.49 \\
(38.63)\end{array}$ & $\begin{array}{c}0.00356^{* * * *} \\
(0.00106)\end{array}$ & $\begin{array}{c}0.0750 \\
(0.0637)\end{array}$ & $\begin{array}{l}-0.00492 \\
(0.0445)\end{array}$ & $\begin{array}{c}0.157 * * * \\
(0.0517)\end{array}$ & $\begin{array}{c}0.000897 * * * \\
(0.000334)\end{array}$ & $\begin{array}{c}0.000901 * * * \\
(0.000335)\end{array}$ \\
\hline Openness & $\begin{array}{l}59.41^{*} \\
(32.55)\end{array}$ & $\begin{array}{c}0.00127 * \\
(0.000733)\end{array}$ & $\begin{array}{l}-0.0165 \\
(0.0186)\end{array}$ & $\begin{array}{l}-0.0272 \\
(0.0241)\end{array}$ & $\begin{array}{l}-0.0219 \\
(0.0205)\end{array}$ & $\begin{array}{l}-0.000123 \\
(0.000121)\end{array}$ & $\begin{array}{c}-0.000118 \\
(0.000123)\end{array}$ \\
\hline Inflation & $\begin{array}{l}15.65^{*} \\
-8.500\end{array}$ & $\begin{array}{c}-5.14 \mathrm{e}-05 \\
(0.000240)\end{array}$ & $\begin{array}{l}-0.00163 \\
(0.00388)\end{array}$ & $\begin{array}{c}0.00871 \\
(0.00651)\end{array}$ & $\begin{array}{c}-0.0380 * * * \\
(0.0121)\end{array}$ & $\begin{array}{l}-6.74 \mathrm{e}-05^{*} \\
(3.77 \mathrm{e}-05)\end{array}$ & $\begin{array}{l}-7.23 e-05^{*} \\
(4.18 \mathrm{e}-05)\end{array}$ \\
\hline Urban Population & $\begin{array}{l}-145.9 * \\
(86.64)\end{array}$ & $\begin{array}{c}0.00180 \\
(0.00658)\end{array}$ & $\begin{array}{l}0.00424 \\
(0.0992)\end{array}$ & $\begin{array}{l}0.0664 \\
(0.151)\end{array}$ & $\begin{array}{l}-0.0666 \\
(0.206)\end{array}$ & $\begin{array}{c}0.000103 \\
(0.000769)\end{array}$ & $\begin{array}{c}0.000177 \\
(0.000767)\end{array}$ \\
\hline Urban1M & $\begin{array}{l}-152.2 \\
(138.5)\end{array}$ & $\begin{array}{l}-0.00254 \\
(0.00487)\end{array}$ & $\begin{array}{l}-0.0229 \\
(0.0413)\end{array}$ & $\begin{array}{l}0.0668 \\
(0.105)\end{array}$ & $\begin{array}{l}-0.0761 \\
(0.0986)\end{array}$ & $\begin{array}{l}-0.000278 \\
(0.000429)\end{array}$ & $\begin{array}{l}-0.000275 \\
(0.000425)\end{array}$ \\
\hline Population & $\begin{array}{c}-2.51 \mathrm{e}-05^{* * * *} \\
(7.97 \mathrm{e}-06)\end{array}$ & $\begin{array}{c}1.59 \mathrm{e}-09 \\
(1.04 \mathrm{e}-09)\end{array}$ & $\begin{array}{l}8.60 \mathrm{e}-09^{*} \\
(5.15 \mathrm{e}-09)\end{array}$ & $\begin{array}{c}3.69 \mathrm{e}-08^{* * * *} \\
(1.03 \mathrm{e}-08)\end{array}$ & $\begin{array}{c}3.50 \mathrm{e}-09 \\
(1.31 \mathrm{e}-08)\end{array}$ & $\begin{array}{c}2.21 \mathrm{e}-10^{* * * *} \\
(8.22 \mathrm{e}-11)\end{array}$ & $\begin{array}{c}2.30 \mathrm{e}-10 * * * \\
(8.27 \mathrm{e}-11)\end{array}$ \\
\hline Constant & $\begin{array}{c}22,503 * * * \\
(6,620)\end{array}$ & $\begin{array}{c}8.652 * * * \\
(0.510)\end{array}$ & $\begin{array}{c}66.73 * * * \\
-6.137\end{array}$ & $\begin{array}{c}66.42 * * * \\
(10.04)\end{array}$ & $\begin{array}{c}66.05 * * * \\
(12.67)\end{array}$ & $\begin{array}{c}0.620 * * * \\
(0.0511)\end{array}$ & $\begin{array}{c}0.610 * * * \\
(0.0517)\end{array}$ \\
\hline Time Fixed Effects & YES & YES & YES & YES & YES & YES & YES \\
\hline Country Fixed Effects & YES & YES & YES & YES & YES & YES & YES \\
\hline Observations & 819 & 819 & 819 & 819 & 819 & 819 & 819 \\
\hline $\mathrm{R}^{2}$ & 0.614 & 0.780 & 0.558 & 0.492 & 0.495 & 0.814 & 0.815 \\
\hline Number of coun_id & 63 & 63 & 63 & 63 & 63 & 63 & 63 \\
\hline
\end{tabular}

Note: Robust standard errors in parentheses. $* * * p<0.01, * * p<0.05, * p<0.1$. Interaction: Small $=1$ if the country has an average population over the 1995-2010 period below 1 million inhabitants. Interaction: Dev=1 if the country is labeled as Developed according to the UN composition of economic regions. 
Table 6. Sensitivity analysis of the tourism indicator

\begin{tabular}{|c|c|c|c|c|c|c|c|c|c|c|}
\hline \multirow[b]{2}{*}{$\begin{array}{l}\text { Variable } \\
\text { Transformation }\end{array}$} & \multicolumn{2}{|c|}{ Arrivals/km2 } & \multicolumn{2}{|c|}{ TourismExpend/km2 } & \multicolumn{2}{|c|}{ Rooms $/ \mathrm{km} 2$} & \multirow{2}{*}{$\begin{array}{c}\begin{array}{c}\text { Principal } \\
\text { Components }\end{array} \\
\text { Logs }\end{array}$} & \multirow{2}{*}{$\begin{array}{c}\begin{array}{c}\text { Standardized } \\
\text { Comp Index } \\
(\mathrm{X} / \mathrm{km} 2)\end{array} \\
\text { Logs }\end{array}$} & \multirow{2}{*}{$\begin{array}{c}\begin{array}{c}\text { Standardized } \\
\text { Comp Index } \\
(\mathrm{X} / \mathrm{pop})\end{array} \\
\text { Logs }\end{array}$} & \multirow{2}{*}{$\begin{array}{c}\text { Tourismindex } \\
\S \\
\text { Van der } \\
\text { Waerden }\end{array}$} \\
\hline & $\log s$ & $\begin{array}{l}\text { Van der } \\
\text { Waerden }\end{array}$ & $\log s$ & $\begin{array}{c}\text { Van der } \\
\text { Waerden }\end{array}$ & $\log s$ & $\begin{array}{c}\text { Van der } \\
\text { Waerden }\end{array}$ & & & & \\
\hline Tourism indicator & 0.00505 & 0.0179 & 0.00307 & $0.0389 * * *$ & $0.0118^{* *}$ & 0.0435 & $0.0142 *$ & $0.0254 *$ & $0.0197 *$ & $0.0829 * * *$ \\
\hline & $(0.00429)$ & $(0.0265)$ & $(0.00276)$ & $(0.0131)$ & $(0.00561)$ & $(0.0273)$ & $(0.00713)$ & $(0.0128)$ & $(0.0115)$ & $(0.0264)$ \\
\hline Controls & YES & YES & YES & YES & YES & YES & YES & YES & YES & YES \\
\hline Time Fixed Effects & YES & YES & YES & YES & YES & YES & YES & YES & YES & YES \\
\hline $\begin{array}{l}\text { Country Fixed } \\
\text { Effects }\end{array}$ & YES & YES & YES & YES & YES & YES & YES & YES & YES & YES \\
\hline Observations & 819 & 819 & 819 & 819 & 819 & 819 & 819 & 819 & 819 & 819 \\
\hline $\mathrm{R} 2$ & 0.810 & 0.808 & 0.809 & 0.812 & 0.814 & 0.810 & 0.813 & 0.813 & 0.813 & 0.813 \\
\hline
\end{tabular}

Note: Robust standard errors in parentheses. $* * * \mathrm{p}<0.01, * * \mathrm{p}<0.05, * \mathrm{p}<0.1$. $\S$ Corresponds to the basic results, displayed in column 3 of Table 4 
Table 7. Dynamic inclusion of tourism

\begin{tabular}{lcccccc} 
& \multicolumn{7}{c}{ Tourism Lags } \\
\cline { 2 - 7 } & $0 \S$ & 1 & 2 & 3 & 4 & 5 \\
\hline Tourism Index & $0.0829 * * *$ & $0.0672 * *$ & $0.0525^{* *}$ & 0.0436 & 0.0394 & 0.0303 \\
& $(0.0264)$ & $(0.0255)$ & $(0.0255)$ & $(0.0271)$ & $(0.0276)$ & $(0.0330)$ \\
Controls & YES & YES & YES & YES & YES & YES \\
Time Fixed Effects & YES & YES & YES & YES & YES & YES \\
Country Fixed & YES & YES & YES & YES & YES & YES \\
Effects & 819 & 756 & 693 & 630 & 567 & 504 \\
Observations & 63 & 63 & 63 & 63 & 63 & 63 \\
Countries & 13 & 12 & 11 & 10 & 9 & 8 \\
Years & 0.813 & 0.810 & 0.804 & 0.789 & 0.783 & 0.773 \\
$\mathrm{R}^{2}$ & & &
\end{tabular}

Note: Robust standard errors in parentheses. $* * * \mathrm{p}<0.01, * * \mathrm{p}<0.05, * \mathrm{p}<0.1$. $\S$ Corresponds to the basic results, displayed in column 3 of Table 4 . 
Table 8. Dynamic and endogenous models

\begin{tabular}{|c|c|c|c|c|}
\hline & (1) & (2) & (3) & (4) \\
\hline & GLS & $\begin{array}{c}\text { Sys } \\
\text { GMM }\end{array}$ & $\begin{array}{c}\text { Sys } \\
\text { GMM }\end{array}$ & GMM \\
\hline \multirow[t]{2}{*}{ HDI t-1 } & & 0.8798 & 0.8939 & \\
\hline & & $(0.0563)$ & (0.0413) & \\
\hline TourismIndex & $\begin{array}{c}0.01995 * * \\
(0.0098)\end{array}$ & $\begin{array}{l}0.0306^{*} \\
(0.0157)\end{array}$ & $\begin{array}{l}0.0339^{*} \\
(0.0189)\end{array}$ & $\begin{array}{c}0.0810 * * \\
(0.0338)\end{array}$ \\
\hline rho & 0.9223 & & & \\
\hline
\end{tabular}

AR(1) Arellano Bond test (p-val)

$0.000 \quad 0.000$

AR(2) Arellano Bond test (p-val)

$0.780 \quad 0.629$

Controls

Time Fixed Effects

YES YES YES YES

Country Fixed Effects

YES

Tourisminstrumented

NO YES YES

Hansen overid (p-val)

$\begin{array}{lll}0.126 & 0.125 & 0.253\end{array}$

Note: Standard errors in parentheses. $* * * p<0.01, * * p<0.05,{ }^{*} p<0.1$. 


\section{APPENDIX 1}

\section{Table A1.1 List of Countries}

\begin{tabular}{|c|c|c|c|}
\hline 1 & Australia & 33 & Latvia \\
\hline 2 & Austria & 34 & Morocco \\
\hline 3 & Belgium & 35 & Madagascar \\
\hline 4 & Bangladesh & 36 & Mexico \\
\hline 5 & Bolivia & 37 & Mali \\
\hline 6 & Botswana & 38 & Mauritius \\
\hline 7 & Chile & 39 & Malaysia \\
\hline 8 & China & 40 & Niger \\
\hline 9 & Costa Rica & 41 & Nicaragua \\
\hline 10 & Cyprus & 42 & Norway \\
\hline 11 & Denmark & 43 & Oman \\
\hline 12 & Dominican Republic & 44 & Pakistan \\
\hline 13 & Ecuador & 45 & Panama \\
\hline 14 & Egypt & 46 & Philippines \\
\hline 15 & Spain & 47 & Poland \\
\hline 16 & Fiji & 48 & Portugal \\
\hline 17 & France & 49 & Paraguay \\
\hline 18 & Ghana & 50 & Romania \\
\hline 19 & Greece & 51 & Russia \\
\hline 20 & Guatemala & 52 & El Salvador \\
\hline 21 & Croatia & 53 & Slovenia \\
\hline 22 & Indonesia & 54 & Sweden \\
\hline 23 & India & 55 & Swaziland \\
\hline 24 & Ireland & 56 & Togo \\
\hline 25 & Iceland & 57 & Trinidad and Tobago \\
\hline 26 & Israel & 58 & Tunisia \\
\hline 27 & Italy & 59 & Turkey \\
\hline 28 & Jordan & 60 & Ukraine \\
\hline 29 & Japan & 61 & Uruguay \\
\hline 30 & Korea & 62 & United States \\
\hline 31 & Lithuania & 63 & Venezuela \\
\hline 32 & Luxembourg & & \\
\hline
\end{tabular}


Table A1.2. Variables description.

\begin{tabular}{|c|c|c|}
\hline Label & Description & Source \\
\hline Hybrid HDI & Hybrid HDI values, $\mathrm{HDI}=\left(\text { Lifex } * \mathrm{EDUx}^{*} \mathrm{GDPx}\right)^{\wedge}(1 / 3)$ & $\begin{array}{l}\text { United Nations Development Programme - } \\
\text { Human Development Report }\end{array}$ \\
\hline HDI Rank & Hybrid HDI ranks & Human Development Report \\
\hline Life & Life Expectancy & $\begin{array}{l}\text { United Nations Development Programme - } \\
\text { Human Development Report }\end{array}$ \\
\hline Lifex & Health Index, Lifex $=($ Life-20)/(83.166(Japan,2010)-20) & $\begin{array}{l}\text { United Nations Development Programme - } \\
\text { Human Development Report } \\
\text { United Nations Development Programme - }\end{array}$ \\
\hline Lit & Adult Literacy Rate & $\begin{array}{l}\text { Human Development Report } \\
\text { United Nations Development Programme - }\end{array}$ \\
\hline GER & Combined Gross Enrolment Rate & Human Development Report \\
\hline Litx & $\begin{array}{l}\text { Literacy Index, Litx }=(\text { Lit-0)/(99(several countries, several } \\
\text { years)-0) }\end{array}$ & $\begin{array}{l}\text { United Nations Development Programme - } \\
\text { Human Development Report }\end{array}$ \\
\hline GERx & $\begin{array}{l}\text { Combined Gross Enrolment Rate Index, GERx=(GER- } \\
0) /(115.8192 \text { (Australia,2002)-0) }\end{array}$ & $\begin{array}{l}\text { United Nations Development Programme - } \\
\text { Human Development Report } \\
\text { United Nations Development Programme - }\end{array}$ \\
\hline EDUx & Education Index, $\mathrm{EDUx}=(\operatorname{Litx} * \mathrm{GERx})^{\wedge}(1 / 2)$ & $\begin{array}{l}\text { Human Development Report } \\
\text { United Nations Development Programme - }\end{array}$ \\
\hline GDP & $\begin{array}{l}\text { GDP per capita, PPP\$ } \\
\text { Income Index, GDPx }=(\ln (\mathrm{GDP})-\end{array}$ & Human Development Report \\
\hline GDPx & $\begin{array}{l}\ln (163.28143(\text { Liberia,1995))/(ln(106769.74(UAE, 1977))- } \\
\ln (163.28143 \text { (Liberia,1995)) }\end{array}$ & $\begin{array}{l}\text { United Nations Development Programme - } \\
\text { Human Development Report }\end{array}$ \\
\hline
\end{tabular}

\section{TOURISM INDEX}

Arrivals / Overnight visitors (tourists) in hotels and similar

Arr_Overn

Arrivals / Overnight
establishments ('000)

UNWTO

UNWTO

Rooms Number of rooms in hotels and similar establishments (Units)

Exp_total Tourism expenditure of inbound tourists US\$ Mn

UNWTO

PWT 7.1. Alan Heston, Robert Summers and

Bettina Aten, Penn World Table Version 7.1

Center for International Comparisons of

GOVERNMENT Government Consumption Share of PPP Converted GDP Per Production, Income and Prices at the University of CONSUMPTION Capita at 2005 constant prices [rgdpl] (\%) Pennsylvania, Nov 2012

PWT 7.1. Alan Heston, Robert Summers and Bettina Aten, Penn World Table Version 7.1, Center for International Comparisons of

Investment Share of PPP Converted GDP Per Capita at 2005

Production, Income and Prices at the University of INVESTMENT constant prices [rgdpl] (\%)

Pennsylvania, Nov 2012.

PWT 7.1. Alan Heston, Robert Summers and Bettina Aten, Penn World Table Version 7.1, Center for International Comparisons of

Production, Income and Prices at the University of OPENESS Openness at 2005 constant prices (\%) Pennsylvania, Nov 2012.

\begin{tabular}{ll}
\hline INFLATION & Inflation, GDP deflator (annual \%) \\
\hline URBAN & Urban population (\% of total) \\
POPULATION & $\begin{array}{l}\text { Population in urban agglomerations of more than 1 million } \\
\text { (\% of total population) }\end{array}$
\end{tabular}
World Development Indicators

World Development Indicators

World Development Indicators PWT 7.1. Alan Heston, Robert Summers and Bettina Aten, Penn World Table Version 7.1, Center for International Comparisons of Production, Income and Prices at the University of 
Table A1.3 Descriptive statistics of independent variables

\begin{tabular}{|c|c|c|c|c|c|c|}
\hline Variable & Mean & Std. Dev. & Min & Max & $\mathrm{Ob}$ & \\
\hline Tour overall & 0.4909965 & 0.2762485 & 0.0163626 & 0.9826649 & $\mathrm{~N}$ & 988 \\
\hline between & & 0.277176 & 0.022546 & 0.9803027 & $\mathrm{n}$ & 76 \\
\hline within & & 0.0205119 & 0.4031377 & 0.5906543 & $\mathrm{~T}$ & 13 \\
\hline Hybrid I overall & 0.7195145 & 0.1519848 & 0.2046213 & 0.9346673 & $\mathrm{~N}$ & 819 \\
\hline between & & 0.1518212 & 0.252418 & 0.9207171 & $\mathrm{n}$ & 63 \\
\hline within & & 0.0196937 & 0.6583344 & 0.7814838 & $\mathrm{~T}$ & 13 \\
\hline GDP overall & 15340.73 & 14338.71 & 618.1713 & 81101.25 & $\mathrm{~N}$ & 819 \\
\hline between & & 14268.42 & 645.4272 & 68390.36 & $\mathrm{n}$ & 63 \\
\hline within & & 2235.454 & 40.37544 & 28051.61 & $\mathrm{~T}$ & 13 \\
\hline lgdp overall & 9.116191 & 1.141377 & 6.426765 & 11.30345 & $\mathrm{~N}$ & 819 \\
\hline between & & 1.142278 & 6.469537 & 11.12472 & $\mathrm{n}$ & 63 \\
\hline within & & 0.1307082 & 8.647418 & 9.656493 & $\mathrm{~T}$ & 13 \\
\hline Life overall & 71.26526 & 8.287484 & 44.011 & 82.81 & $\mathrm{~N}$ & 819 \\
\hline between & & 8.249114 & 46.35931 & 81.71562 & $\mathrm{n}$ & 63 \\
\hline within & & 1.277798 & 66.89933 & 79.96333 & $\mathrm{~T}$ & 13 \\
\hline Lit overall & 86.15913 & 18.64464 & 7.949133 & 99 & $\mathrm{~N}$ & 819 \\
\hline between & & 18.62679 & 17.66532 & 99 & $\mathrm{n}$ & 63 \\
\hline within & & 2.398952 & 76.44295 & 100.1102 & $\mathrm{~T}$ & 13 \\
\hline GER overall & 75.51401 & 17.2506 & 16.54183 & 115.8192 & $\mathrm{~N}$ & 819 \\
\hline between & & 16.85983 & 21.62185 & 113.3418 & $\mathrm{n}$ & 63 \\
\hline within & & 4.1832 & 61.34994 & 89.86664 & $\mathrm{~T}$ & 13 \\
\hline $\mathrm{kg} \quad$ overall & 8.178923 & 3.619082 & 3.064907 & 22.38491 & $\mathrm{~N}$ & 819 \\
\hline between & & 3.537901 & 3.485376 & 21.17157 & $\mathrm{n}$ & 63 \\
\hline within & & 0.8744325 & 3.859887 & 12.724 & $\mathrm{~T}$ & 13 \\
\hline ki overall & 23.80495 & 7.53997 & 1.751632 & 54.26286 & $\mathrm{~N}$ & 819 \\
\hline between & & 6.501228 & 11.46984 & 44.4118 & $\mathrm{n}$ & 63 \\
\hline within & & 3.899387 & 5.07827 & 44.89533 & $\mathrm{~T}$ & 13 \\
\hline openk overall & 80.57232 & 42.61747 & 20.28251 & 326.541 & $\mathrm{~N}$ & 819 \\
\hline between & & 41.51492 & 24.4223 & 270.7436 & $\mathrm{n}$ & 63 \\
\hline within & & 10.86475 & 27.76718 & 136.3697 & $\mathrm{~T}$ & 13 \\
\hline pop_urb overall & 60.95598 & 20.32137 & 9.8642 & 97.3904 & $\mathrm{~N}$ & 819 \\
\hline between & & 20.39831 & 11.36365 & 97.16098 & $\mathrm{n}$ & 63 \\
\hline within & & 1.723614 & 53.89961 & 68.69393 & $\mathrm{~T}$ & 13 \\
\hline pop_1M overall & 17.82686 & 15.61716 & 0 & 60.50578 & $\mathrm{~N}$ & 819 \\
\hline between & & 15.68967 & 0 & 60.23725 & $\mathrm{n}$ & 63 \\
\hline within & & 1.158034 & 14.58584 & 36.1112 & $\mathrm{~T}$ & 13 \\
\hline pop_tot overall & 70100000 & 210000000 & 268916 & $1.32 \mathrm{E}+09$ & $\mathrm{~N}$ & 819 \\
\hline between & & 211000000 & 288943 & $1.28 \mathrm{E}+09$ & $\mathrm{n}$ & 63 \\
\hline within & & 9636005 & -35200000 & 173000000 & $\mathrm{~T}$ & 13 \\
\hline infl_G d overall & 7.872425 & 12.64169 & -23.47888 & 147.3057 & $\mathrm{~N}$ & 819 \\
\hline between & & 8.57216 & -0.993961 & 43.12494 & $\mathrm{n}$ & 63 \\
\hline within & & 9.349243 & -29.03158 & 117.6934 & $\mathrm{~T}$ & 13 \\
\hline
\end{tabular}


Table A1.4 Panel Unit Root Tests

\begin{tabular}{|lcccccc|}
\hline Variables & $\begin{array}{c}\text { LLC } \\
\text { (constant) }\end{array}$ & $\begin{array}{c}\text { LLC } \\
\text { (constant+trend) }\end{array}$ & $\begin{array}{c}\text { Fisher_DF } \\
\text { (constant) }\end{array}$ & $\begin{array}{c}\text { Fisher_DF } \\
\text { (constant+trend) }\end{array}$ & $\begin{array}{c}\text { Fisher_PP } \\
\text { (constant) }\end{array}$ & $\begin{array}{c}\text { Fisher_PP } \\
\text { (constant+trend) }\end{array}$ \\
\hline HDI & $-8.29^{* * *}$ & $-7.40^{* * *}$ & $160.87^{*}$ & $181.24^{* * *}$ & $319.43^{* * *}$ & 135.53 \\
Tourism & $-7.53^{* * *}$ & $-13.51^{* * *}$ & 146.13 & $178.47^{* * *}$ & $171.94^{* *}$ & $170.94^{* *}$ \\
\hline
\end{tabular}

Note: $* * *, * *$ are the significance levels at $10 \%, 5 \%$ and, $1 \%$ respectively. LLC is distributed as $\mathrm{N}(0,1)$ under the null hypothesis of non-stationarity. Fisher test is chi-square distributed with $2 \mathrm{~N}$ degrees of freedom. The LLC (Levin-Lin-Chu, 2002) tests the null hypothesis of the presence of unit roots in homogenous panel and assumes that all series are stationary under the alternative; Fisher test performs a unit-root test on each panel series separately, next it combines the p-values to get an overall test of whether the panel series contains a unit root (Baltagi, 2013). As it can be seen from the performed tests, the variables are stationary. 


\begin{abstract}
APPENDIX 2
Tourism is proxied through three alternative variables: Tourism expenditures of inbound tourists; Total number of rooms in hotels and similar establishments; and Tourism arrivals in hotels and similar establishments. All variables can be expressed in absolute and also in relative terms with respect to every country's total area or to population, and also in the original units of measurement or in logs.

Regarding the composite indices, in addition to the Tourism Index described in section 3, several alternatives are considered here.

5. An additional index has been created using Principal Components Analysis (PCA; Jolliffe, 2002). Again, all three variables are considered. Given the high correlation between them, only one factor is needed to account for more than $83 \%$ of the total variance for raw data and $77 \%$ for variables in logs, and in both cases is the only one with an eigenvalue larger than one. Consequently, we consider one principal component, which in turn is a weighted linear combination of the original variables. One principal component is computed for variables in levels and one for variables in logs.

6. Besides, we have also built several composite indices by means of the simple average of the standardized values of the three considered variables.

1. All tourism variables, standardized by area

2. All tourism variables, standardized by area, in logs

3. All tourism variables, standardized by population

4. All tourism variables, standardized by population, in logs
\end{abstract}

The descriptive statistics of all variables and indices are presented below.

Clearly, the tourism variables in levels are highly skewed and with high values of the Kurtosis index. The same results are found for all composite indicators resulting from them: Principal Components levels and the Standardized Index 1 - (km2) and Stand. Index 3 - (pop). This form is largely alleviated once the variables are expressed in $\operatorname{logs}$ (index 2 and Index 4) or when the use of rankings is considered (see the Tourism Index and all variables expressed in terms of the Van der Waerden metrics).

The correlation matrices of raw data and data once country and time fixed effects are taking into account report how the three indices are only slightly correlated

Consequently the Tourism Index based on the Van der Waerden is correlated with the composite indices based on the standardized variables expressed in logs. 
Table A2.1 Descriptive statistics

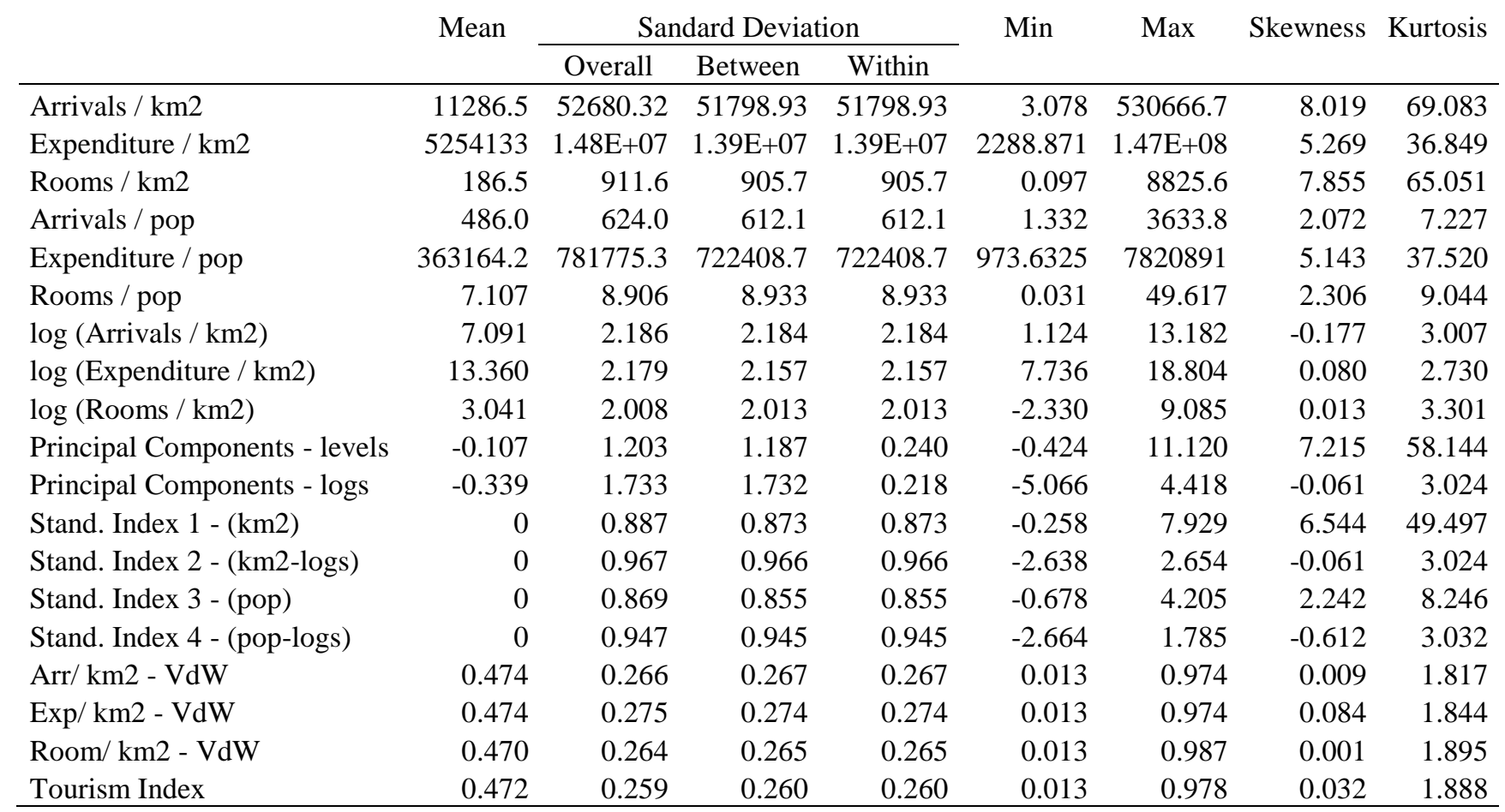


Table A2.2 Correlation coefficients. Raw data.

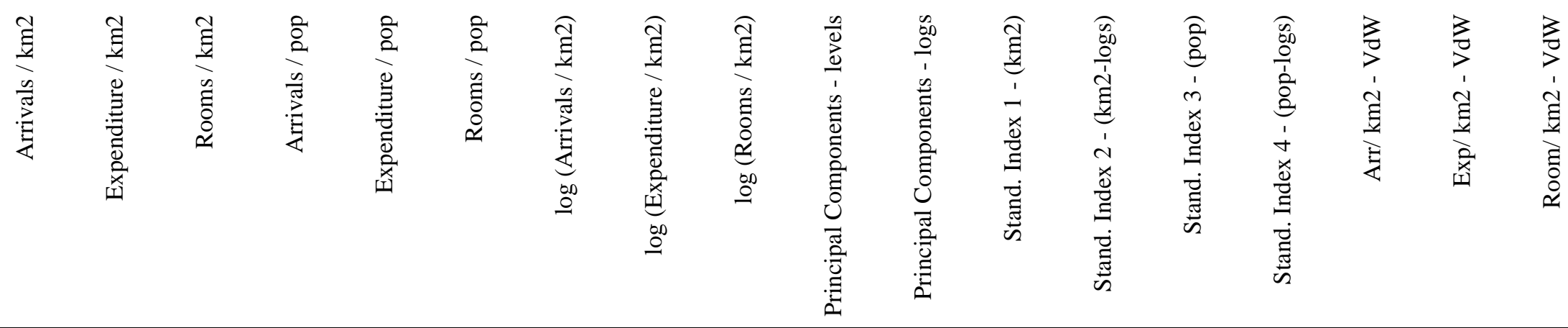

\begin{tabular}{|c|c|c|c|c|c|c|c|c|c|c|c|c|c|c|c|c|c|c|}
\hline Expenditure / km2 & 0.541 & & & & & & & & & & & & & & & & & \\
\hline Rooms / km2 & 0.994 & 0.508 & & & & & & & & & & & & & & & & \\
\hline Arrivals / pop & 0.071 & 0.301 & 0.042 & & & & & & & & & & & & & & & \\
\hline Expenditure / pop & 0.030 & 0.701 & -0.007 & 0.618 & & & & & & & & & & & & & & \\
\hline Rooms / pop & 0.074 & 0.196 & 0.078 & 0.838 & 0.440 & & & & & & & & & & & & & \\
\hline $\log$ (Arrivals / km2) & 0.429 & 0.501 & 0.409 & 0.548 & 0.321 & 0.497 & & & & & & & & & & & & \\
\hline $\log$ (Expenditure / km2) & 0.357 & 0.602 & 0.343 & 0.508 & 0.493 & 0.506 & 0.894 & & & & & & & & & & & \\
\hline $\begin{array}{l}\log (\text { Rooms / km2) } \\
\text { Principal Components - }\end{array}$ & 0.452 & 0.501 & 0.452 & 0.453 & 0.284 & 0.562 & 0.916 & 0.898 & & & & & & & & & & \\
\hline levels & 0.982 & 0.684 & 0.975 & 0.119 & 0.174 & 0.111 & 0.477 & 0.442 & 0.505 & & & & & & & & & \\
\hline Principal Components - logs & 0.427 & 0.553 & 0.415 & 0.520 & 0.378 & 0.540 & 0.968 & 0.962 & 0.970 & 0.491 & & & & & & & & \\
\hline Stand. Index 1 - (km2) & 0.952 & 0.770 & 0.940 & 0.156 & 0.272 & 0.131 & 0.503 & 0.489 & 0.528 & 0.992 & 0.524 & & & & & & & \\
\hline Stand. Index 2 - (km2-logs) & 0.427 & 0.553 & 0.415 & 0.520 & 0.378 & 0.540 & 0.969 & 0.962 & 0.970 & 0.491 & 1.000 & 0.524 & & & & & & \\
\hline Stand. Index 3 - (pop) & 0.067 & 0.460 & 0.044 & 0.942 & 0.790 & 0.874 & 0.524 & 0.578 & 0.498 & 0.155 & 0.552 & 0.214 & 0.552 & & & & & \\
\hline Stand. Index 4 - (pop-logs) & 0.105 & 0.326 & 0.089 & 0.730 & 0.528 & 0.710 & 0.713 & 0.709 & 0.659 & 0.159 & 0.717 & 0.195 & 0.717 & 0.755 & & & & \\
\hline Arr/ km2 - VdW & 0.338 & 0.473 & 0.316 & 0.570 & 0.322 & 0.522 & 0.972 & 0.864 & 0.885 & 0.391 & 0.938 & 0.423 & 0.938 & 0.542 & 0.708 & & & \\
\hline Exp/ km2 - VdW & 0.318 & 0.532 & 0.307 & 0.513 & 0.448 & 0.527 & 0.874 & 0.969 & 0.877 & 0.393 & 0.937 & 0.435 & 0.938 & 0.571 & 0.705 & 0.885 & & \\
\hline Room/ km2 - VdW & 0.339 & 0.459 & 0.337 & 0.469 & 0.290 & 0.587 & 0.891 & 0.876 & 0.973 & 0.398 & 0.945 & 0.426 & 0.945 & 0.516 & 0.678 & 0.905 & 0.894 & \\
\hline Tourism Index & 0.344 & 0.507 & 0.332 & 0.536 & 0.368 & 0.565 & 0.946 & 0.937 & 0.945 & 0.408 & 0.975 & 0.444 & 0.975 & 0.564 & 0.723 & 0.964 & 0.962 & 0.967 \\
\hline
\end{tabular}


Table A2.3 Correlation coefficients. Adjusted data, once controlled by country and time effects.

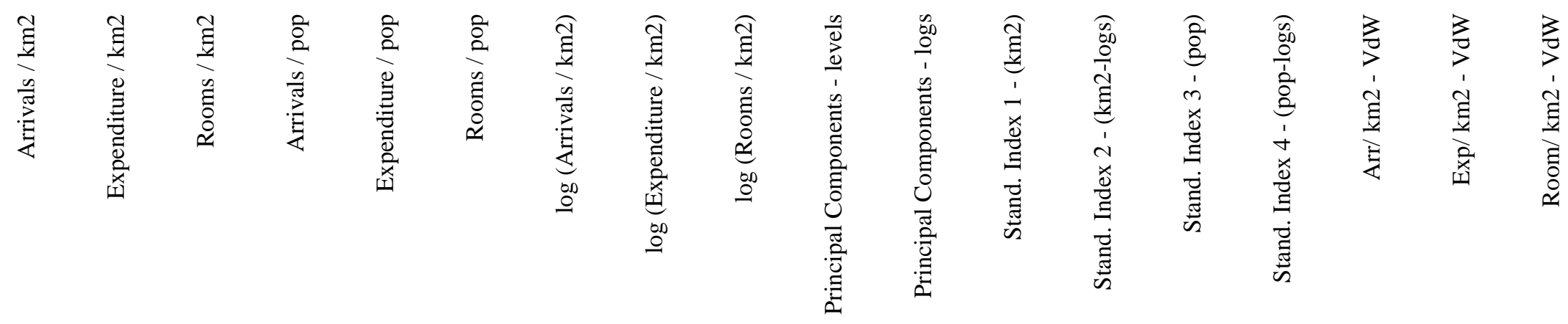

\begin{tabular}{|c|c|c|c|c|c|c|c|c|c|c|c|c|c|c|c|c|c|}
\hline Arrivals / km2 & & & & & & & & & & & & & & & & & \\
\hline Expenditure / km2 & 0.202 & & & & & & & & & & & & & & & & \\
\hline Rooms / km2 & 0.971 & 0.182 & & & & & & & & & & & & & & & \\
\hline Arrivals / pop & 0.059 & -0.048 & -0.012 & & & & & & & & & & & & & & \\
\hline Expenditure / pop & -0.030 & 0.771 & -0.048 & 0.233 & & & & & & & & & & & & & \\
\hline Rooms / pop & 0.058 & -0.220 & 0.089 & 0.370 & 0.001 & & & & & & & & & & & & \\
\hline $\log$ (Arrivals / km2) & 0.052 & -0.150 & 0.011 & 0.479 & -0.120 & 0.098 & & & & & & & & & & & \\
\hline $\log ($ Expenditure / km2) & -0.078 & 0.085 & -0.073 & 0.072 & 0.183 & 0.022 & 0.228 & & & & & & & & & & \\
\hline $\log ($ Rooms / km2) & 0.012 & -0.183 & 0.047 & -0.066 & -0.185 & 0.329 & 0.219 & 0.164 & & & & & & & & & \\
\hline $\begin{array}{l}\text { Principal Components - } \\
\text { levels }\end{array}$ & 0.912 & 0.576 & 0.901 & 0.004 & 0.287 & -0.031 & -0.033 & -0.029 & -0.053 & & & & & & & & \\
\hline Principal Components - logs & -0.019 & -0.085 & -0.022 & 0.240 & -0.012 & 0.181 & 0.681 & 0.776 & 0.573 & -0.053 & & & & & & & \\
\hline Stand. Index $1-(\mathrm{km} 2)$ & 0.799 & 0.747 & 0.784 & -0.010 & 0.448 & -0.087 & -0.069 & 0.000 & -0.094 & 0.974 & -0.066 & & & & & & \\
\hline Stand. Index 2 - (km2-logs) & -0.019 & -0.085 & -0.023 & 0.241 & -0.012 & 0.181 & 0.683 & 0.777 & 0.570 & -0.052 & 1.000 & -0.066 & & & & & \\
\hline Stand. Index 3 - (pop) & 0.011 & 0.534 & -0.026 & 0.660 & 0.866 & 0.333 & 0.124 & 0.175 & -0.111 & 0.217 & 0.123 & 0.325 & 0.123 & & & & \\
\hline Stand. Index 4 - (pop-logs) & -0.026 & -0.074 & -0.034 & 0.301 & 0.009 & 0.216 & 0.665 & 0.786 & 0.474 & -0.056 & 0.962 & -0.066 & 0.963 & 0.170 & & & \\
\hline Arr/ km2 - VdW & 0.061 & 0.011 & 0.009 & 0.487 & -0.003 & -0.024 & 0.776 & 0.211 & 0.078 & 0.037 & 0.515 & 0.033 & 0.516 & 0.196 & 0.497 & & \\
\hline $\mathrm{Exp} / \mathrm{km} 2-\mathrm{VdW}$ & -0.004 & 0.063 & -0.010 & 0.126 & 0.132 & 0.016 & 0.259 & 0.823 & 0.086 & 0.021 & 0.653 & 0.034 & 0.654 & 0.157 & 0.670 & 0.250 & \\
\hline Room/ km2 - VdW & 0.009 & -0.002 & 0.024 & -0.038 & -0.050 & 0.246 & 0.074 & 0.090 & 0.743 & 0.012 & 0.365 & 0.010 & 0.363 & -0.010 & 0.303 & 0.064 & 0.074 \\
\hline
\end{tabular}


Tourism Index 